Hydrogeology and Water-Quality Conditions at the City of Olathe Landfill, East-Central Kansas, 1990-93

By PATRICK P. RASMUSSEN, JOHNETTE C. SHOCKLEY, and DIRK A. HARGADINE

U.S. GEOLOGICAL SURVEY

Water-Resources Investigations Report 94-4166

Prepared in cooperation with the

CITY OF OLATHE, KANSAS

Lawrence, Kansas

1994 


\section{U.S. DEPARTMENT OF THE INTERIOR BRUCE BABBITT, Secretary}

\section{U.S. GEOLOGICAL SURVEY}

Gordon P. Eaton, Director

For additional information write to:

Copies of this report can be purchased from:

District Chief

U.S. Geological Survey

Water Resources Division

4821 Quail Crest Place

Lawrence, Kansas 66049-3839
U.S. Geological Survey Earth Science Information Center Open-File Reports Section Box 25286, MS 517 Denver Federal Center Denver, Colorado 80225 


\section{CONTENTS}

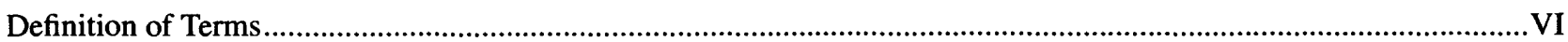

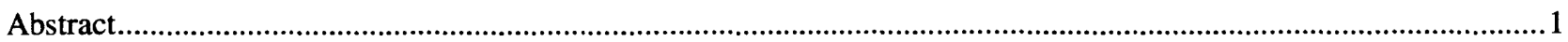

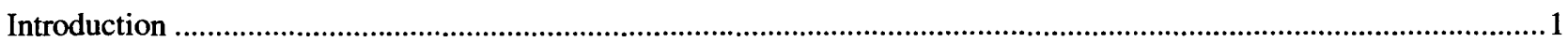

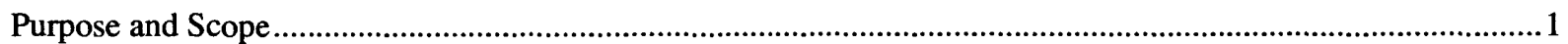

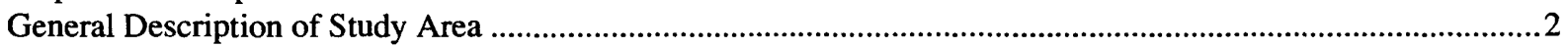

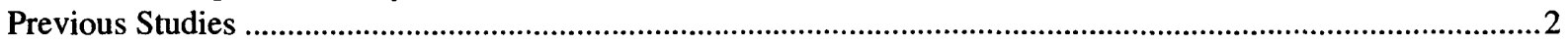

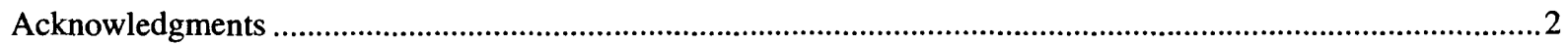

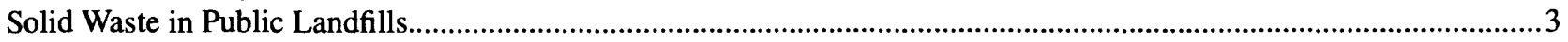

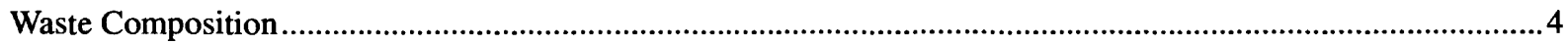

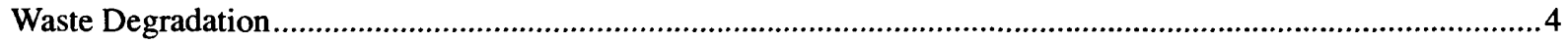

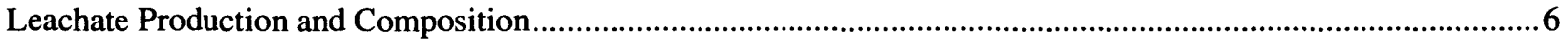

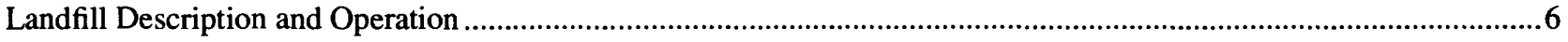

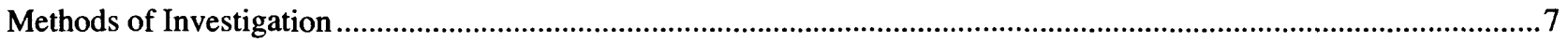

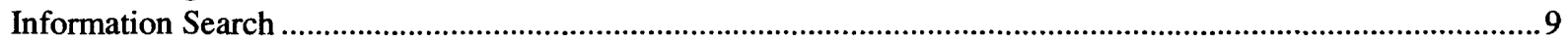

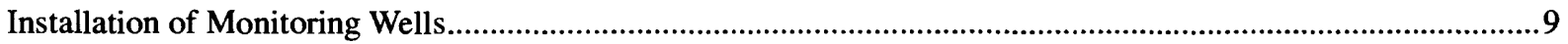

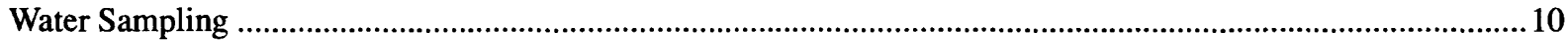

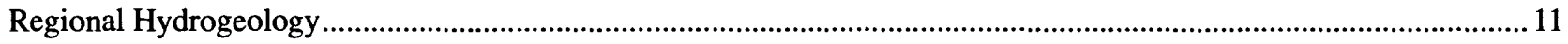

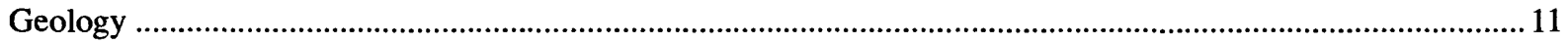

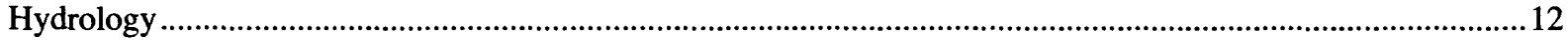

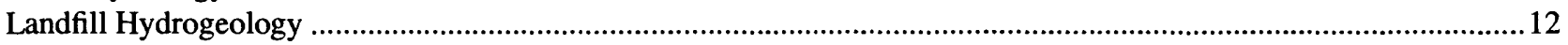

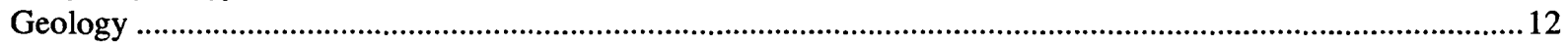

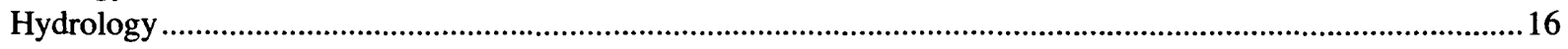

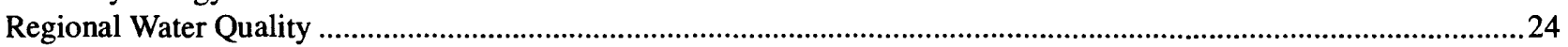

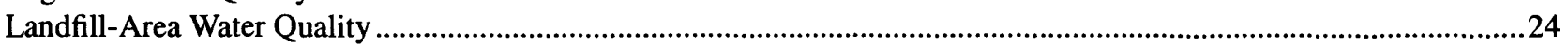

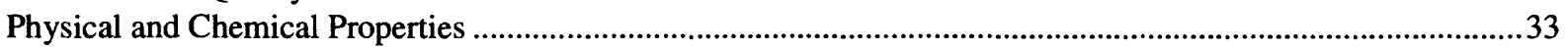

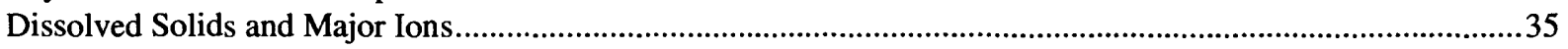

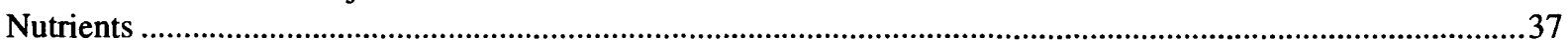

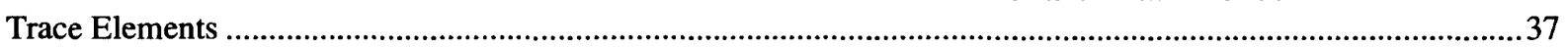

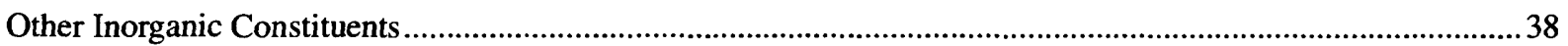

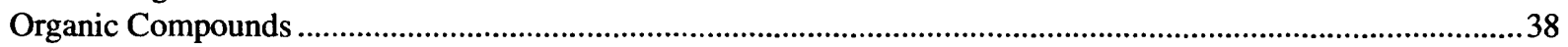

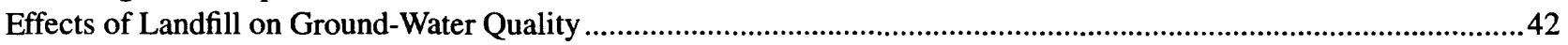

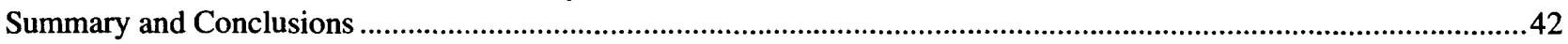

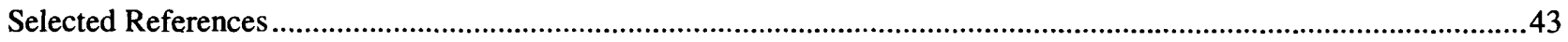

\section{FIGURES}

1. Maps showing location of the City of Olathe Landfill and topography in vicinity of Olathe, Kansas .................... 3

2. Graphs showing degradation phases and components of an idealized, homogeneous landfill cell and methane-generating anaerobic decomposition process.

3. Map showing landfill features, location of monitoring wells and surface-water sampling sites, and traces of

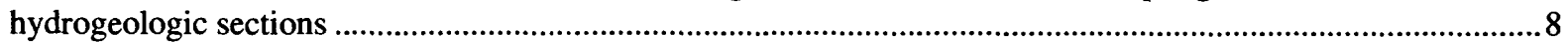

4. Diagram showing generalized monitoring-well design ................................................................................ 10

5. Generalized stratigraphic section showing formal geologic units in vicinity of the City of Olathe Landfill.........13

6. Hydrogeologic sections in vicinity of the City of Olathe Landfill showing lithology and screened intervals....... 14 


\section{FIGURES-Continued}

7-11. Maps showing:

7. Potentiometric surfaces in aquifers in the Plattsburg Limestone and Wyandotte Limestone on July 31, 1992, and in the Plattsburg Limestone and Wyandotte Limestone on April 7, 1993, City of Olathe Landfill and vicinity

8. Modified Stiff diagrams of major-ion concentrations in water samples from monitoring wells and surface-water sampling sites, December 1990-February 1991, City of Olathe Landfill and vicinity ...........34

9. Distribution of dissolved-solids concentrations in water in vicinity of the City of Olathe Landfill,

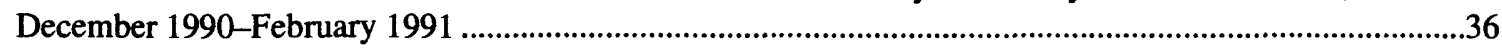

10. Distribution of iron and manganese concentrations in water in vicinity of the City of Olathe Landfill, December 1990-February 1991

11. Distribution of benzene concentrations in water in vicinity of the City of Olathe Landfill, December 1990-February 1991

\section{TABLES}

1. Average monthly temperature and precipitation at Olathe, Kansas, 1974-92.

2. Typical moisture contents of newly disposed municipal solid-waste components .................................................4

3. Typical values of physical properties and typical concentrations of chemical constituents in landfill leachate.

4. Top-of-casing altitudes, total depths, and screened-interval depths of monitoring wells in vicinity of the City of Olathe Landfill

5. Water-column volumes purged from monitoring wells in December 1990 before sampling at the City of Olathe Landfill

6. Water-level altitudes in monitoring wells in vicinity of the City of Olathe Landfill, December 1990-April 1993.

7. Physical properties and constituent concentrations in water from monitoring wells and surface-water sampling sites, City of Olathe Landfill and vicinity, December 1990-February 1991

8. Organic compounds analyzed in water samples from monitoring wells and surface-water sampling sites, City of Olathe Landfill and vicinity

9. Organic compounds detected in water samples from monitoring wells and surface-water sampling sites, City of Olathe Landfill and vicinity, December 1990-February 1991

10. Organic compounds detected in ground-water samples collected in the vicinity of the City of Olathe Landfill, January and February 1991 
CONVERSION FACTORS AND VERTICAL DATUM

\begin{tabular}{rcl}
\hline Multiply & By & To obtain \\
\hline inch & 2.54 & centimeter \\
foot & 0.3048 & meter \\
mile & 1.609 & kilometer \\
square mile & 2.590 & square kilometer \\
acre & 0.4047 & hectare \\
acre-foot & 1,233 & cubic meter \\
gallon & 3.785 & liter \\
cubic foot & 0.02832 & cubic meter \\
gallon per minute & 0.06309 & liter per second \\
foot per mile & 0.1894 & meter per kilometer \\
ton, short & 0.9072 & megagram \\
\hline
\end{tabular}

To convert temperature in degrees Fahrenheit $\left({ }^{\circ} \mathrm{F}\right)$ to degrees Celsius $\left({ }^{\circ} \mathrm{C}\right)$, use the following equation:

$$
{ }^{\circ} \mathrm{C}=\left({ }^{\circ} \mathrm{F}-32\right) / 1.8 \text {. }
$$

Sea level: In this report, "sea level" refers to the National Geodetic Vertical Datum of 1929 (NGVD of 1929) - a geodetic datum derived from a general adjustment of the first-order level nets of both the United States and Canada, formerly called Sea Level Datum of 1929. 


\section{DEFINITION OF TERMS}

Aerobic. Living, active, or occurring only in the presence of free oxygen.

Alluvium. Sediment deposited by flowing rivers.

Alkalinity. The capacity of solutes to react with and neutralize acid in a solution.

Anaerobic. Living, active, or occurring in the absence of free oxygen.

Aquifer. A body of rock that contains sufficient saturated permeable material to yield significant quantities of water to wells and springs.

Chemical oxygen demand. A measure of the quantity of chemically oxidizable material present in water.

Confined aquifer. Aquifer in which ground water is confined under pressure that is substantially greater than atmospheric pressure.

Dissolution. A process of chemical weathering by which material passes into solution.

Equipotential hine. A line in a two-dimensional groundwater flow field such that the total hydraulic head is the same for all points along the line.

Hardness. A measure of the amount of calcium and magnesium carbonates dissolved in water.

Hydraulic conductivity. The rate of flow of water at the prevailing kinematic viscosity that will move through a porous medium in unit time under a unit hydraulic gradient through a unit area measured at right angles to the direction of flow. Units of hydraulic conductivity are:

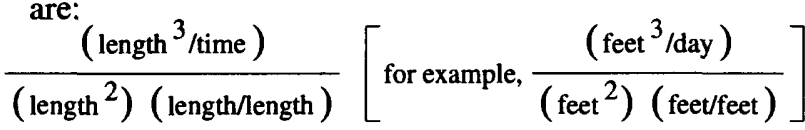

but, as in this report, commonly are simplified and reported as length/time (for example, feet per day).

Hydraulic gradient. Rate of change in total hydraulic head per unit of distance of flow in a given direction.

Hydraulic head. Height above a stated datum of the surface of a water column that can be supported by the static pressure at a given point.

Hydrolysis. A chemical decomposition process involving the splitting of a chemical bond and the addition of the two ions that comprise water (hydrogen and hydroxide).

Immiscible. Said of two or more phases that, at mutual equilibrium, cannot dissolve completely in one another (for example, oil and water).
Ion exchange. Reversible exchange of ions contained in a crystal for different ions in solution without destroying crystal structure or disturbing electrical neutrality.

Osmosis. The movement at unequal rates of a solvent through a semipermeable membrane, which usually separates the solvent and a solution, until the solutions on both sides of the membrane are equally concentrated.

Oxidation. A process in a chemical reaction whereby an atom or molecule loses electrons.

pH. A measure of the negative logarithm of the hydrogenion activity, in moles per liter.

Porosity. Ratio of the volume of void spaces in a rock or sediment to the total volume of the rock or sediment.

Potentiometric surface. A surface that represents the levels to which water will rise in a tightly cased well. If the hydraulic head varies considerably with depth in an aquifer, there may be more than one potentiometric surface for that aquifer.

Redox. Reduction-oxidation chemical reactions in which electrons are transferred from one atom or molecule to another. An atom or molecule that losses electrons (thus increasing its charge) is said to be oxidized, whereas an atom or molecule that gains electrons (thus decreasing its charge) is said to be reduced. In the reaction $\mathrm{Fe}($ metal $)+\mathrm{Cu}^{2+} \rightarrow \mathrm{Fe}^{2+} \mathrm{Cu}($ metal $)$, the iron is oxidized, and the copper is reduced.

Sorption. The binding of a substance by another by any mechanism, such as absorption, adsorption, or a combination of the two.

Specific conductance. A measure of the ability of water to conduct an electrical current, which in turn is related to the concentration of ionized substances in the water.

Symbiotic. The intimate association of two dissimilar organisms in a mutually beneficial relationship.

Transmissivity. The capacity of an aquifer to transmit water of the prevailing kinematic velocity. The transmissivity of an aquifer is equal to hydraulic conductivity of the aquifer multiplied by the saturated thickness of the aquifer.

Unconfined aquifer. Aquifer whose upper surface is a water table free to fluctuate. 


\title{
Hydrogeology and Water-Quality Conditions at the City of Olathe Landfill, East-Central Kansas, 1990-93
}

\author{
By Patrick P. Rasmussen, Johnette C. Shockley, and Dirk A. Hargadine
}

\section{Abstract}

Water quality in the vicinity of the City of Olathe Landfill in east-central Kansas was examined in relation to hydrogeologic conditions to help determine the effects of the landfill on shallow ground water. This study focused on the Wyandotte and Plattsburg Limestones. The Wyandotte Limestone underlies the entire landfill, whereas the overlying Plattsburg Limestone crops out within the landfill boundaries. Little Cedar Creek, an unnamed tributary, and a pond are located in the landfill.

Water samples from seven monitoring wells and five surface-water sites in the vicinity of the City of Olathe Landfill were collected for analysis of inorganic and organic constituents. The inorganic constituents in the ground water that are most affected in the vicinity of the landfill are calcium, magnesium, sodium, bicarbonate, ammonia, barium, iron, and manganese. The dissolved-organic-carbon concentration at a seep flowing from the Plattsburg Limestone was 1,400 milligrams per liter, indicating that the landfill is affecting the water quality near the seep. Benzene was detected in all of the water samples, and the largest concentration was in a sample collected upgradient of the landfill. The benzene concentration exceeded the U.S.

Environmental Protection Agency's Maximum Contaminant Level (0.005 milligram per liter) for drinking-water supplies. Six of the eight specific organic compounds detected were found in a water sample collected from the Plattsburg Limestone immediately downgradient of the landfill. No organic compounds, except benzene, were detected in samples collected from the
Wyandotte Limestone downgradient of the landfill.

\section{INTRODUCTION}

Shallow aquifers in east-central Kansas provide water for public and private drinking-water supplies, for irrigation and livestock, and for industrial uses. Information describing the characteristics of the aquifers, the sources and directions of ground-water flow, and the chemical quality of ground and surface water is necessary for sound management of the State's water resources. To gain information about the effects of landfills on water quality, the Kansas Department of Health and Environment (Topeka) requires all public landfills in Kansas to install groundwater monitoring systems (Charles Linn, Kansas Department of Health and Environment, oral commun., 1988). The investigation described here, conducted in cooperation with the City of Olathe, Kansas, from October 1990 through April 1993, is one of several conducted in Kansas by the U.S. Geological Survey that focus on the effects of landfills on the quality of water in shallow aquifers. The objectives of the investigation were to determine the geology, hydrology, and water-quality conditions in the vicinity of the City of Olathe Landfill and to describe the effects of the landfill on shallow ground water and nearby surface water.

\section{Purpose and Scope}

This report describes the physical setting of the City of Olathe Landfill, the fate of waste materials in landfills, in general, and investigative methods used. Data collected during installation of monitoring wells and subsequent water-level measurements are used to describe the geology and hydrology in the vicinity of 
the landfill. Analysis of samples from monitoring wells and from nearby creeks and a seep define the water-quality conditions near the landfill and the effects of the landfill on ground-water quality.

Investigation of the City of Olathe Landfill was performed in four phases. The first was an initial information-gathering phase for the general area and the landfill. The second phase consisted of the installation of monitoring wells to determine the hydrology and geology and to collect water samples. In the third phase, water samples were collected from the monitoring wells and selected surface-water sites and analyzed. This report, which concludes the fourth phase, presents and interprets data obtained during the investigation.

\section{General Description of Study Area}

The City of Olathe Landfill is located in the northwest part of the city of Olathe, Johnson County, Kansas (fig. 1). The original site consisted of 188 acres located in the northwest quarter of section 27 , and a part of the southwest quarter of section 22, Township 13 South, Range 23 East. An additional 122 acres located north of the original site in the southwest quarter of section 22 are expected to provide space for future waste disposal. The present entrance to the landfill site is 1 mile west of Kansas Highway 7 and 1 mile north of Prairie Center Road on Hedge Lane.

Little Cedar Creek flows north along the east and northeast boundary of the landfill site and exits north of the landfill (fig. 1). Little Cedar Creek is part of the Kansas River Basin and drains an area of approximately 3,000 acres. An unnamed tributary of Little Cedar Creek flows north through the west half of the landfill into Little Cedar Creek.

Topographic relief within the landfill boundary is 120 feet. The lowest altitude is approximately 910 feet in the streambed of Little Cedar Creek, and the highest altitude is approximately 1,030 feet on a ridge at the southern boundary of the landfill. The hills are steep with slopes of 16 to more than 30 percent.

The landfill is located on agriculturally zoned pastureland, and adjacent land to the north, west, and south is used predominately for farming and cattle grazing. The Ernie Miller Nature Park is located to the east.

The landfill site is in a region with a wide range in monthly and annual temperature extremes, and with hot summers, cold winters, and uneven rainfall distribution throughout the year (table 1). The average annual temperature and precipitation for Olathe from 1974 through 1992 was $55.0^{\circ} \mathrm{F}$ and 38.0 inches, respectively (National Oceanic and Atmospheric Administration, 1974-92). During this period, the maximum monthly precipitation (12.4 inches) and minimum monthly precipitation ( 0 inch) occurred in 1990 and 1989, respectively.

\section{Previous Studies}

One report pertains to the effects of the City of Olathe Landfill on water quality; analyses of surfacewater quality were presented in the City of Olathe, Existing Landfill Site Operations Evaluation Report (Bucher, Willis, and Ratliff, Consulting Engineers, written commun., 1985), which listed concentrations of constituents found in water samples collected from the streams adjacent to the landfill site. In that study, two water samples were collected from Little Cedar Creek, one upstream and one downstream of the landfill; a third sample was collected from the unnamed tributary within the landfill boundary, 300 feet from the confluence with Little Cedar Creek. Samples collected from Little Cedar Creek were analyzed for 30 inorganic and 2 organic constituents; the sample collected from the unnamed tributary was analyzed for 12 inorganic and 2 organic constituents. The results indicated that two organic compounds [diethylphthalate and bis(2-ethylhexyl) phthalate] were detected in the downstream sample from Little Cedar Creek.

The geology and the ground-water resources of Johnson County, Kansas, are described by O'Connor (1971). O'Connor reports well yields and analyses of ground-water samples collected from wells screened in various limestone aquifers in the county.

\section{Acknowledgments}

The authors extend appreciation to Diane Utz, City of Olathe Solid Waste Manager, for assistance in coordinating the study and for providing information about the history and operation of the landfill. Appreciation also is expressed to James Kenny Beach, Landfill Team Leader, for the use of landfill facilities and assistance during field work. 


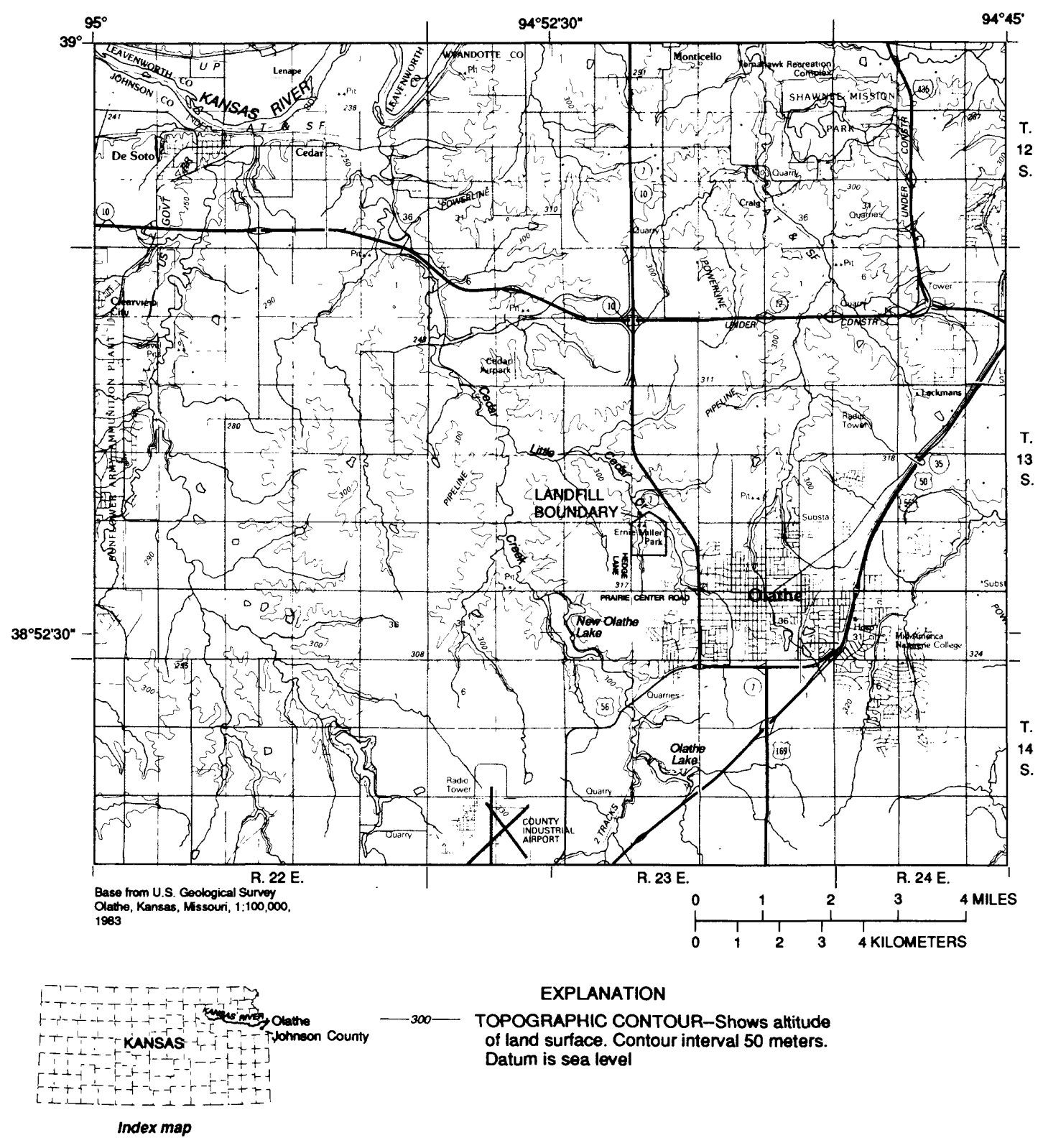

Figure 1. Location of the City of Olathe Landfill and topography in vicinity of Olathe, Kansas.

\section{SOLID WASTE IN PUBLIC LANDFILLS}

Solid wastes are materials that are no longer of value or are no longer perceived to be of value to the individual or community and, therefore, are discarded. The following is a general discussion of solid-waste composition, solid-waste degradation, and leachate production and composition in landfills. Much of the discussion is modified from Myers and Bigsby (1989). Although the exact composition of the solid waste and the chemical processes in the City of Olathe Landfill are not known, they can be inferred to be similar to the general compositions and chemical processes reported in the literature. 
Table 1. Average monthly temperature and precipitation at Olathe, Kansas, 1974-92

[Data from National Oceanic and Atmospheric Administration, 1974-92]

\begin{tabular}{|c|c|c|c|c|c|c|c|c|c|c|c|c|}
\hline Jan. & Feb. & Mar. & Apr. & May & June & July & Aug. & Sept. & Oct. & Nov. & Dec. & $\begin{array}{c}\text { Yearly } \\
\text { average } \\
\text { for } \\
1974-92\end{array}$ \\
\hline \multicolumn{13}{|c|}{ Average temperature, in degrees Fahrenheit } \\
\hline 30.2 & 35.8 & 47.8 & 57.8 & 68.6 & 77.6 & 83.5 & 80.8 & 72.7 & 60.5 & 44.0 & 32.4 & 55.0 \\
\hline \multicolumn{13}{|c|}{ Average precipitation, in inches } \\
\hline 1.27 & 1.23 & 2.88 & 3.68 & 5.57 & 5.53 & 2.98 & 4.01 & 4.24 & 3.86 & 2.60 & 1.53 & 38.0 \\
\hline
\end{tabular}

\section{Waste Composition}

Typical nationwide composition of landfill solid waste, by weight, is 45 percent paper, 15 percent food and kitchen waste, 11 percent yard and garden trimmings, 9 percent metal, 8 percent glass, 4 percent dirt, ashes, and concrete, 3 percent textiles, 3 percent plastics, and 2 percent wood (Tchobanoglous and others, 1977). About 80 percent of the solid waste is combustible. Total amounts of fixed carbon, water, and volatile organic matter represent 7,20 , and 53 percent of the solid waste, respectively. Solid-waste composition varies because of climate, season, recycling, demography, packaging, and marketing (Tchobanoglous and others, 1977).

\section{Waste Degradation}

About 80 percent of typical solid waste, including paper, food and kitchen waste, yard and garden trimmings, and ferrous metal, can be degraded. The other 20 percent, mostly glass, wood, rubber, plastics, and synthetic textiles, degrades very slowly

(Tchobanoglous and others, 1977). Degradation processes in the landfill include biologic decomposition, dissolution, precipitation, sorption, ion exchange, and diffusion of gases (Baedecker and Back, 1979).

Sufficient moisture content, 20 to 60 percent, is essential for appreciable degradation rates. The moisture content depends on the composition of the waste, the climate, the age and thickness of the landfill material, and other factors (Tchobanoglous and others, 1977). Typical moisture contents for new solid waste are listed in table 2.

Degradation phases and components of an idealized, homogeneous landfill cell are represented in figure 2 (Christensen and others, 1989). Phase 1 represents the aerobic phase (oxidizing environment).
Aerobic degradation proceeds rapidly and probably begins in easily degradable waste soon after deposition. Net products primarily are carbon dioxide and water, plus sulfate and ammonia (Baedecker and Back, 1979). The water produced by aerobic degradation increases the amount of moisture available for subsequent anaerobic degradation processes.

When oxygen is depleted by aerobic degradation, methane-generating anaerobic degradation of the organic waste begins. Anaerobic degradation dominates in the reducing environment of phases 2 through

Table 2. Typical moisture contents of newly disposed municipal solid-waste components

[Modified from Tchobanoglous and others, 1977]

\begin{tabular}{lrc}
\hline \multirow{2}{*}{ Component } & \multicolumn{2}{c}{ Moisture content, in percent } \\
\cline { 2 - 3 } Food waste & $50-80$ & 70 \\
Paper & $4-10$ & 6 \\
Cardboard & $4-8$ & 5 \\
Plastics & $1-4$ & 2 \\
Textiles & $6-15$ & 10 \\
Rubber & $1-4$ & 2 \\
Leather & $8-12$ & 10 \\
Garden trimmings & $30-80$ & 60 \\
Wood & $15-40$ & 20 \\
Glass & $1-4$ & 2 \\
Tin cans & $2-4$ & 3 \\
Nonferrous metals & $2-4$ & 2 \\
Ferrous metals & $2-6$ & 3 \\
Dirt, ash, brick, and & $6-12$ & 8 \\
$\quad$ other & & \\
& & \\
Municipal solid wastes & $15-40$ & 20 \\
$\quad$ composite of above & & \\
components) & & \\
\hline
\end{tabular}



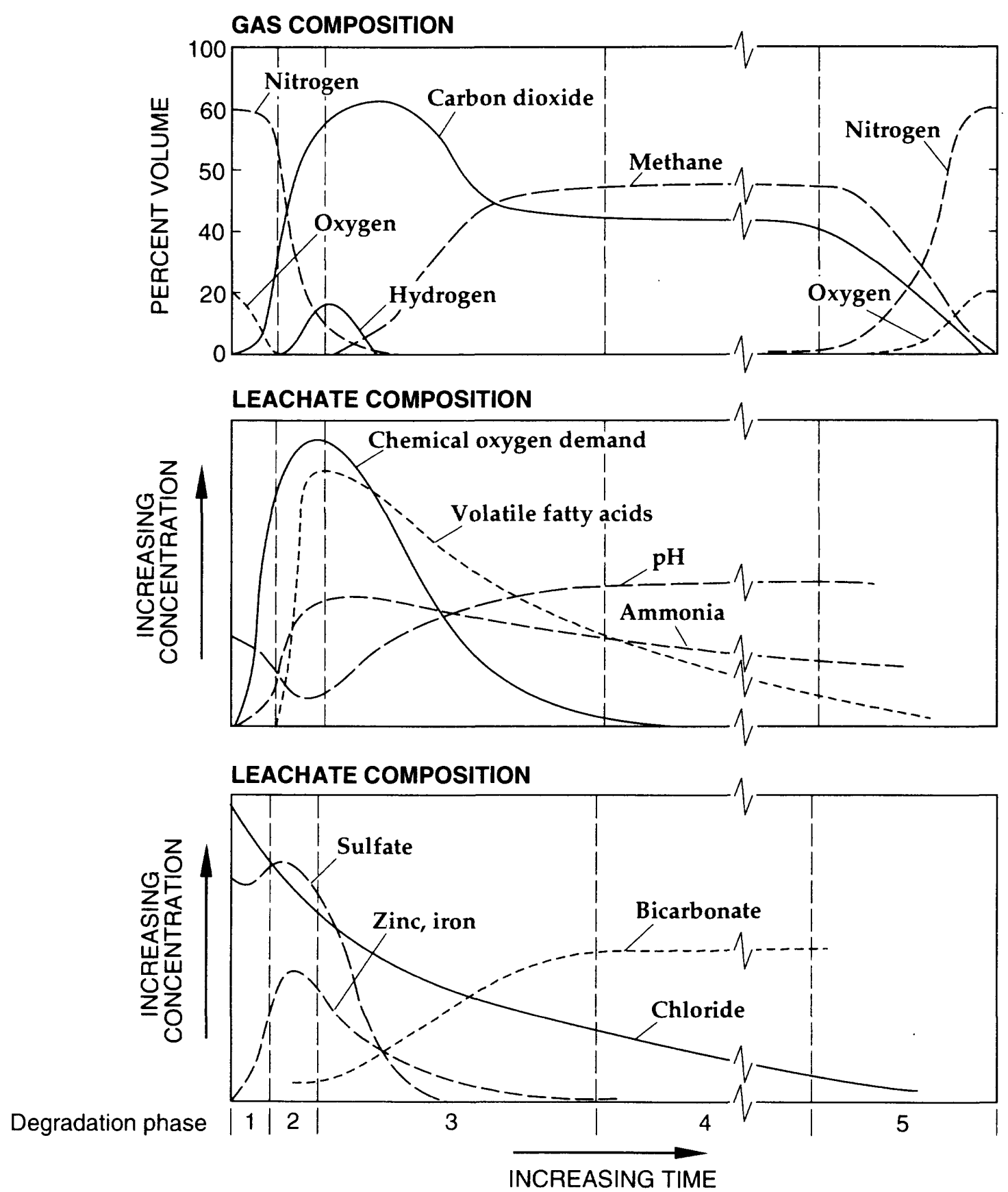

Figure 2. Degradation phases and components of an idealized, homogeneous landfill cell and methane-gathering anaerobic decomposition process (modified from Christiansen and others, 1989).

4 (fig. 2). Phase 5 (fig. 2) is characterized by decreased methane production, increased nitrogen concentrations in the landfill gas, and aerobic zones in the upper layers of the landfill. During phase 5, methane formation becomes minimal, and nitrogen diffuses from the atmosphere into the soil. End products of the fully completed anaerobic degradation are methane, water, and carbon dioxide (Baedecker and Back, 1979).
At any specific time, specific parts of the same landfill may be in different stages of degradation. The stage and rate of degradation will vary by landfill, depending primarily on moisture content but also on temperature and on local procedures for shredding, mixing, and compacting the waste. The aerobic stage of a waste cell may be completed in a few days or weeks, and anaerobic degradation occurs quickly enough to allow substantial methane production to 
peak within 2 years and then decline for 25 years or more (Tchobanoglous and others, 1977).

\section{Leachate Production and Composition}

Leachate is generated by percolation of water through the waste, and the biological and chemical extraction of dissolved and suspended materials (Tchobanoglous and others, 1977). Paper, which comprises about 45 percent of all landfill waste nationwide, absorbs most of the water originally available in the waste. Therefore, the production and discharge of leachate from a landfill above the water table requires the infiltration of water downward from the land surface. Initially, waste is unsaturated, and most percolating water is retained by the waste, particularly paper products. Once the waste becomes nearly saturated, lateral and downward movement of leachate results. Solids, gases, and liquids from the waste are incorporated into the leachate as dissolved, suspended, or sorbed components that may be either miscible or immiscible. Carbon dioxide, produced by bacterial action, dissolves easily, decreasing leachate $\mathrm{pH}$. The resulting dissolution of calcium carbonate, if present, increases hardness and dissolved solids. The solvent capability of the leachate also is increased by the bacterially generated organic acids, which causes some metals in the landfill to dissolve.

Chemical processes in leachate production are oxidation, reduction, dissolution, precipitation, ion exchange, and sorption. In the landfill, these processes are affected to a large degree by the types of organic compounds present (Baedecker and Back, 1979). Physical processes contributing to leachate production are settlement, movement of evolved and ejected water, entrainment of colloidal and particulate material in percolating water, filtration, change of solute concentration by osmosis and concentration gradients, density separation of immiscible phases, and vertical and horizontal migration of gases.

Leachate composition is variable. Some typical concentrations and composition ranges of the most abundant constituents are listed in table 3 . Where ranges are given, the larger values are expected in newer landfills because these are undergoing more rapid early-stage biodegradation involving acid production. Sodium and potassium tend to remain in solution, unadsorbed by clay when calcium is present. Bicarbonate is produced directly in anaerobic reactions and indirectly when carbon dioxide dissolves.
Bicarbonate also is dissolved from landfill ash, soil, and rock. Sulfate, derived from ash and treatment wastes, may be reduced within the landfill anaerobic environment and precipitated as ferrous sulfide or evolved as hydrogen sulfide gas, but sulfate otherwise is nonreactive. Chloride is nonreactive, and its concentration in leachate varies primarily because of dilution. Nitrogen is present mostly as ammonia because of conditions stemming from anaerobic decomposition and the presence of dissolved iron (Apgar and Langmuir, 1971). Iron and manganese commonly are present in leachate in large concentrations (table 3). These constituents can be derived from wastes and also from oxide coatings and cements in soil and rock.

Leachate can contain trace elements such as cadmium, chromium, cobalt, copper, lead, mercury, nickel, strontium, and zinc in detectable concentrations. Other environmentally significant elements detected in landfill leachate include arsenic, boron, and selenium. These elements can occur naturally in the environment or can be derived from the landfill wastes. Elements present at concentrations greater than natural background concentrations likely are derived from municipal and industrial wastes or dissolution of natural compounds by leachate.

\section{LANDFILL DESCRIPTION AND OPERATION}

The City of Olathe Landfill site covers about 188 acres of former pastureland approximately 2 miles northwest of Olathe, Kansas (fig. 1). The old covered section of the landfill occupies the north part of the 188 acres (fig. 3 ). The active part of the landfill occupies an area along the east boundary of the landfill. The city has an additional 122 acres of pastureland, north of the present northern boundary, for expansion.

The old section of the City of Olathe Landfill was operated as a sanitary landfill beginning in 1974. Wastes were compacted and covered daily with soil. The original land-surface altitude before the landfill opened is unknown. The thickness of the buried waste in this old section also is unknown.

The active section of the landfill accepts 250 to 300 short tons of municipal waste per day. The waste is compacted and covered daily. A pit where empty barrels are dumped north of the active section is shown in figure 3 . West of the active part of the 
Table 3. Typical values of physical properties and typical concentrations of chemical constituents in landfill leachate

[Concentrations in milligrams per liter except as noted; ----, not determined]

\begin{tabular}{|c|c|c|c|c|}
\hline \multirow[b]{2}{*}{ Property or constituent } & \multicolumn{4}{|c|}{ Concentrations } \\
\hline & $\begin{array}{c}\text { Steiner and others, } \\
1971\end{array}$ & $\begin{array}{c}\text { U.S. Environmental } \\
\text { Protection Agency, } \\
1973\end{array}$ & $\begin{array}{c}\text { U.S. Environmental } \\
\text { Protection Agency, } \\
1975\end{array}$ & $\begin{array}{c}\text { Tchobanoglous } \\
\text { and others, } \\
1977\end{array}$ \\
\hline Specific conductance ${ }^{1}$ & $-\cdots$ & --- & $6,000-9,000$ & $-\cdots$ \\
\hline $\mathrm{pH}^{2}$ & $4.0-8.5$ & $3.7-8.5$ & $5.2-6.4$ & 6.0 \\
\hline Chemical oxygen demand & $100-51,000$ & $0-89,520$ & $16,000-22,000$ & 18,000 \\
\hline Hardness, total & $200-5,250$ & $0-22,800$ & $3,500-5,000$ & 3,500 \\
\hline Calcium & --- & $5-4,080$ & $900-1,700$ & ---- \\
\hline Magnesium & ---- & $16.5-15,600$ & $160-250$ & --- \\
\hline Sodium & $100-3,800$ & $0-7,700$ & $450-500$ & 500 \\
\hline Potassium & --- & $2.8-3,770$ & $295-310$ & 300 \\
\hline Alkalinity, total as $\mathrm{CaCO}_{3}$ & --- & $0-20,850$ & $800-4,000$ & 3,000 \\
\hline Sulfate & $25-500$ & $1-1,826$ & $400-50$ & 300 \\
\hline Chloride & $100-2,400$ & $34-2,800$ & $600-800$ & 500 \\
\hline Dissolved solids, total & --- & $0-42,276$ & $10,000-14,000$ & --- \\
\hline Nitrate, total as $\mathrm{N}$ & $20-500$ & $0-1,416$ & --- & 5.6 \\
\hline Phosphate & $5-130$ & $0-154$ & --- & --- \\
\hline Iron & $200-1,700$ & $0.2-5,500$ & $210-325$ & 60 \\
\hline Lead & --- & $0-5.0$ & 1.6 & ---- \\
\hline Manganese & ---- & $0.06-1,400$ & $75-125$ & ---- \\
\hline Zinc & $1-135$ & $0-1,000$ & $10-30$ & --- \\
\hline
\end{tabular}

${ }^{1}$ Concentrations in microsiemens per centimeter at 25 degrees Celsius.

${ }^{2}$ Concentrations in standard units.

landfill, the uppermost limestone has been quarried. The shale below is used for daily and final cover material. Precipitation at and near the quarry has formed a pond on top of the exposed limestone where the upper limestone and shale have been removed. Filling of the quarry with waste is planned when the current active site is full.

A bed for drying (fig. 3) of sludge collected from a nearby wastewater-treatment plant is north of the landfill boundary. Sludge drying began in the early 1980's. The dried sludge is mixed with top soil and used for the top layer of the final landfill cover.

Sludge from a battery manufacturer in Olathe was deposited at the landfill for a 2- to 3-year period beginning in about 1977 . This sludge was separated from other wastes, deposited northwest of the present quarry operation (fig. 3), and left uncovered. The battery sludge was removed in 1986. Surface-water samples were collected from the unnamed tributary to the west and seem to indicate that battery-sludge disposal did not appreciably affect water quality of that tributary (Bucher, Willis, and Ratliff, Consulting Engineers, written commun., 1985). This section now is used for a compost operation that began in April 1990. Bags of leaves and grass are piled in rows, and a moving machine is used to separate the plastic bags from their contents. The rows of grass and leaves are left to decompose. When decomposition is completed, more bags of grass and leaves are added, and the process is repeated.

\section{METHODS OF INVESTIGATION}

Investigation of the City of Olathe Landfill was performed in four phases. The first was an initial information-gathering phase for the general area and the landfill. The information gathering included the landfill's history, the geology and hydrology of the area, and water-quality data available for the vicinity of the landfill. The second phase consisted of the installation of monitoring wells to determine the 


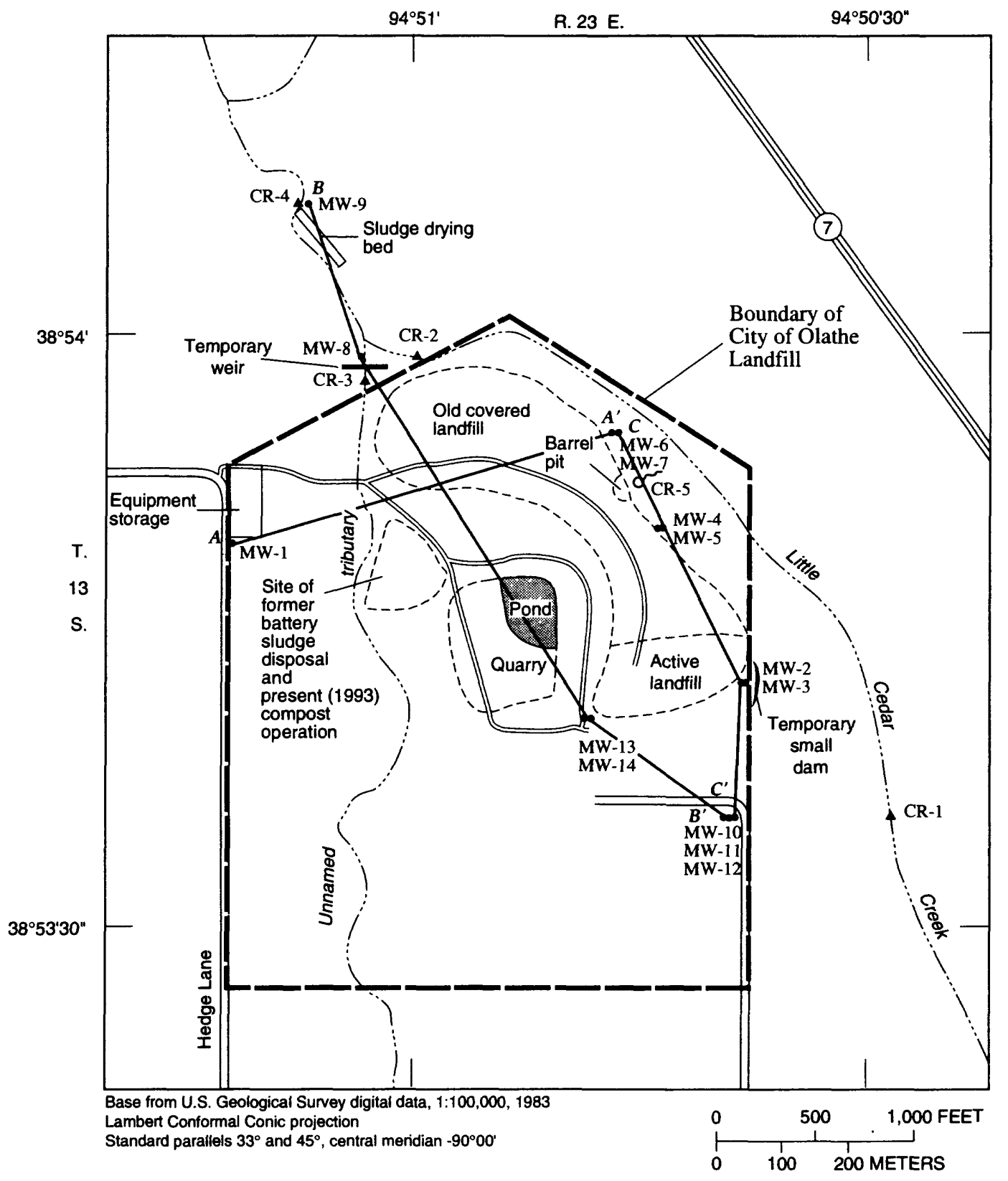

EXPLANATION

$\stackrel{A^{\prime}}{\longrightarrow}$ TRACE OF SECTION-Shown in figure 6

APPROXIMATE BOUNDARY OF LANDFILL FEATURE

- MW-1 MONITORING WELL AND NUMBER

$\triangle$ CR-1 CREEK SAMPLING SITE AND NUMBER

CR-5 SEEP SAMPLING SITE AND NUMBER

Figure 3. Landfill features, location of monitoring wells and surface-water sampling sites, and traces of hydrogeologic sections. 
hydrology and geology and to collect water samples. Locations for the monitoring wells were selected on the basis of the geologic and hydrologic information gathered in phase one. In the third phase, water samples were collected from the monitoring wells and selected surface-water sites and analyzed. This report, which concludes the fourth phase, presents and interprets data obtained during the investigation.

\section{Information Search}

Prior to any work onsite, a search of published literature and files of the Kansas Department of Health and Environment, the Kansas Geological Survey, and the City of Olathe was completed. Preliminary estimates of lithology and ground-water flow directions at the landfill were made on the basis of previous geologic and hydrologic information. This information was useful for planning well locations, data-collection activities, and material requirements for well installation.

\section{Installation of Monitoring Wells}

Fourteen monitoring wells were installed using air-rotary methods with a 4.5-inch diameter tri-cone roller bit. Due to the geologic conditions at the site, air proved to be the most satisfactory circulation medium for rotary drilling. A rotary, screw-type compressor unit was used to provide the air pressure for drilling. To avoid introducing contamination into the borehole, several precautions were taken. The smallest compressor possible was used and supplemented with a submicron air filter to remove oil discharged from the compressor, minimizing oil blow-by. Differential pressure loss due to the filter was monitored to ensure proper filter operation. Drilling was conducted sequentially from what was estimated to be the upgradient to the downgradient sites. Cleaning equipment between boreholes consisted of removing loose cuttings from the bit and drill rod with a wire brush and a high-pressure air jet; the bit and drill rod then were scrubbed with a low-phosphate detergent solution and rinsed with potable water. Potable water was purchased from the City of Olathe and hauled to the site in a stainless-steel tank or was obtained from the rural-water-district tap at the landfill.

Geologic information was collected by examining the cuttings while drilling and by obtaining geophysical logs from three boreholes. Each monitoring well was constructed of a 5-foot, 0.010 -inch slotted, schedule-40, polyvinyl-chloride screen and completed with flush-coupled, threaded, 2 -inch diameter, schedule-40, polyvinyl-chloride pipe to the surface (fig. 4). All pipe was factory washed and individually bagged in plastic prior to installation. Buna-N-Orings ${ }^{1}$ sealed each joint; no glue or cement was applied. Stainless-steel centralizers were used to ensure the casings were centered in the borehole. A 0.0335 - to 0.787 -inch diameter silica-sand filter pack was installed to a point 5 feet above the top of the well screen. Next, 0.375 -inch bentonite chips were added to the borehole up to a depth of about 10 feet below land surface. A steel tape was used to check for possible bridging. Granular bentonite then was added from 10 feet to a point approximately 2 feet below the land surface. Finally, a cement pad was poured on the bentonite seal, and a protective casing with a locking cap was set around the well casing.

After all monitoring wells had been installed, the top-of-casing altitude for each well was determined by a level survey (table 4). Nested monitoring wells were installed at five locations (denoted by the two- or three-well groupings in table 4 and fig. 3) to evaluate vertical ground-water movement. Each well within a nest was screened in a different limestone aquifer.

Water levels in the monitoring wells were measured to the nearest 0.01 foot with a chalked steel tape. Water-level altitudes were used to prepare potentiometric-surface maps to show directions of ground-water flow. Altitudes of the water surface, or hydraulic heads, were computed by subtracting water level, in feet below top of casing, from the top-ofcasing altitude of the well site, in feet above sea level. General descriptions of these types of measurements are given by Heath (1983, p. 72-73). The land-surface altitude of well MW-12 was determined from a U.S. Geological Survey 7.5-minute topographic map with a 10 -foot contour interval. The altitudes of the remainder of the wells were surveyed relative to well MW-12 (using well MW-12 as the known altitude.)

Monitoring wells were developed with a Teflon bailer. Wells with slow recovery rates were bailed dry, left to recover, then bailed dry again. The wells were considered fully developed when the water bailed from the well was clear. Some of the wells had very slow recovery times, taking from 3 to 8 months to recover to a point considered to be the static level.

\footnotetext{
${ }^{1}$ The use of trade names in this report is for identification purposes only and does not constitute endorsement by the U.S. Geological Survey.
} 


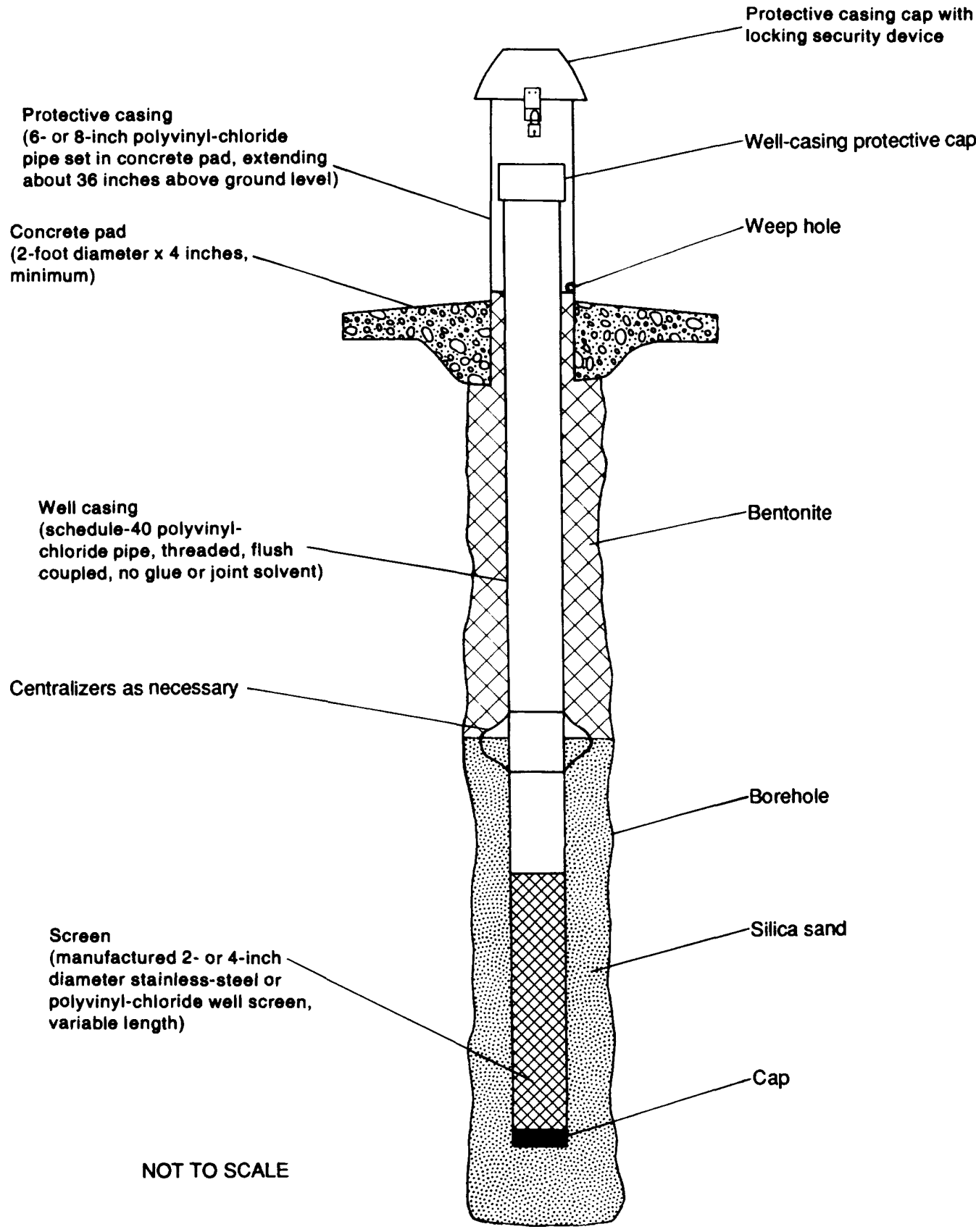

Figure 4. Generalized monitoring-well design.

\section{Water Sampling}

On December 19, 1990, January 26, 1991, and February 26, 1991, seven monitoring wells and five surface-water sampling sites were sampled at the City of Olathe Landfill (fig. 3). The sample collection began with the upgradient well (well MW-1), suspected of having the least potential for contamination, and ended with the downgradient wells (wells MW-2 and MW-6) having the greatest potential for contamination. For the surface-water sampling sites, the sample collection began upstream of the landfill on Little Cedar Creek (sampling site CR-1), moved downstream along the creek, and ended at a seep on the east side of the landfill (sampling site CR-5).

Water levels and total depths in all monitoring wells at the time of sampling were measured to the nearest 0.01 foot with a steel tape, which was precleaned with distilled water before each use. If possible, each monitoring well was purged of five water-column volumes to ensure that water samples collected were representative of the aquifer (wells 
Table 4. Top-of-casing altitudes, total depths, and screened-interval depths of monitoring wells (MW) in vicinity of the City of Olathe Landfill

\begin{tabular}{lccc}
\hline Well & $\begin{array}{c}\text { Top-of- } \\
\text { casing } \\
\text { altitude } \\
\text { (feet above } \\
\text { sea level }\end{array}$ & $\begin{array}{c}\text { Total depth } \\
\text { below land } \\
\text { surface } \\
\text { (feet) }\end{array}$ & $\begin{array}{c}\text { Screened- } \\
\text { interval } \\
\text { depth below } \\
\text { land surface } \\
\text { (feet) }\end{array}$ \\
\hline MW-1 & 994.67 & 74.0 & $69.0-74.0$ \\
MW-2 & 982.87 & 11.5 & $6.5-11.5$ \\
MW-3 & 982.09 & 65.8 & $60.8-65.8$ \\
MW-4 & 987.38 & 10.5 & $5.5-10.5$ \\
MW-5 & 987.46 & 69.7 & $64.7-69.7$ \\
& & & \\
MW-6 & 990.07 & 15.3 & $10.3-15.3$ \\
MW-7 & 989.52 & 67.0 & $62.0-67.0$ \\
MW-8 & 930.50 & 16.5 & $11.5-16.5$ \\
MW-9 & 917.73 & 21.4 & $16.4-21.4$ \\
MW-10 & $1,029.24$ & 35.5 & $30.5-35.5$ \\
& & & \\
MW-11 & $1,029.25$ & 59.6 & $54.6-59.6$ \\
MW-12 & $1,028.59$ & 101.4 & $96.4-101.4$ \\
MW-13 & $1,043.09$ & 67.0 & $62-67$ \\
MW-14 & $1,043.13$ & 107.0 & $102-107.0$ \\
\hline
\end{tabular}

MW-6, MW-8, MW-9, MW-12). Several wells were bailed dry and required a considerable amount of time to recover ( 3 to 8 months). If the well recovered by February 26, 1991, then a sample was collected (wells MW-1, MW-2, MW-10). Wells that did not recover within this time were not sampled (wells MW-3, MW-4, MW-5, MW-7, MW-11). The volume of water to be purged from each well was determined from water-level and total-depth measurements (table 5). Wells were purged with a Teflon-bottom check-valve bailer that was suspended from a new nylon cord and cleaned with a low-phosphate detergent solution and rinsed with distilled, deionized water before each use. Water samples were collected with the same bailer used to purge the well.

Water samples from wells were collected in the following order: (1) volatile organic compounds, (2) semivolatile organic compounds, (3) chemical oxygen demand, (4) dissolved organic carbon and dissolved common ions, and (5) dissolved trace elements and dissolved nutrients. Care was taken to minimize aeration of the water when collecting the samples. The samples for chemical oxygen demand, dissolved nutrients, and dissolved trace elements were preserved with chemicals. All samples, except common-ion and trace-metal samples, were chilled and maintained at $4{ }^{\circ} \mathrm{C}$. Dissolved-organic-carbon samples were filtered onsite through a 0.2 -micron silver filter, and common-ion, nutrient, and traceelement samples were filtered at the U.S. Geological Survey laboratory in Lawrence, Kansas, through a 0.45-micron glass filter. Both types of filters were preflushed with about 500 milliliters of sample water before collecting the sample to be analyzed. Specificconductance, $\mathrm{pH}$, water-temperature, and alkalinity measurements were determined at the time of sample collection. These data for monitoring wells MW-6, MW-8, MW-9, and MW-12 were not properly recorded and, consequently, are not included in this report. Surface-water samples were processed in the same order as previously described. Samples were collected and analyzed for an abbreviated list of volatile organic compounds from Little Cedar Creek, its unnamed tributary, and a seep.

Water samples then were mailed to the U.S. Geological Survey laboratory in Arvada, Colorado, for analysis. Constituents were analyzed according to U.S. Geological Survey methods for determination of inorganic substances (Fishman and Friedman, 1989) and organic substances in water (Wershaw and others, 1987).

\section{REGIONAL HYDROGEOLOGY}

The descriptions of regional geology in Johnson County and hydrology that follow provide a framework for the more detailed discussion of landfill hydrogeology later in this report.

\section{Geology}

The regional geology in Johnson County consists mainly of rocks of Pennsylvanian age, with unconsolidated sand and gravel deposits of Quaternary age locally overlying the bedrock. Rocks of Pennsylvanian age are mainly alternating beds of limestone and shale and include some local sandstone (O'Connor, 1971). The average dip is about 12 feet per mile to the northwest.

The Quaternary-age deposits, where present on the flood plains and terraces, consist of variable mixtures of gravel, sand, silt, and clay that range from a few feet to about 100 feet in thickness. The deposits primarily are water-laid (fluvial) sediment. 
Table 5. Water-column volumes purged from monitoring wells in December 1990 before sampling at the City of Olathe Landfill

[--, not computed]

\begin{tabular}{|c|c|c|c|c|}
\hline $\begin{array}{l}\text { Well } \\
\text { (fig. 3) }\end{array}$ & $\begin{array}{l}\text { Nominal } \\
\text { diameter } \\
\text { of well }{ }^{1} \\
\text { (inches) }\end{array}$ & $\begin{array}{l}\text { Height of } \\
\text { water } \\
\text { column } \\
\text { in well } \\
\text { casing } \\
\text { (feet) }\end{array}$ & $\begin{array}{l}\text { Volume of } \\
\text { water in } \\
\text { well }^{2} \\
\text { (gallons) }\end{array}$ & $\begin{array}{l}\text { Volume of } \\
\text { water } \\
\text { purged } \\
\text { (gallons) }\end{array}$ \\
\hline MW-1 & 2 & 4.19 & 0.68 & 2.0 \\
\hline MW-2 & 2 & dry & - & - \\
\hline MW-3 & 2 & 1.52 & .25 & 2.0 \\
\hline MW-4 & 2 & dry & - & - \\
\hline MW-5 & 2 & dry & -- & -- \\
\hline MW-6 & 2 & 3.34 & .54 & 2.0 \\
\hline MW-7 & 2 & dry & - & -- \\
\hline MW-8 & 2 & 9.20 & 1.50 & 3.5 \\
\hline MW-9 & 2 & 14.09 & 2.30 & 2.0 \\
\hline MW-10 & 2 & 1.01 & .16 & 2.0 \\
\hline MW-11 & 2 & dry . & - & -- \\
\hline MW-12 & 2 & 7.69 & 1.25 & 2.0 \\
\hline MW-13 & 2 & \multicolumn{3}{|c|}{ not installed until 1992} \\
\hline MW-14 & 2 & \multicolumn{3}{|c|}{ not installed until 1992} \\
\hline
\end{tabular}

\footnotetext{
${ }^{1}$ The actual inside diameter of 2 -inch well casing is 2.067 inches. well is:

${ }^{2}$ The equation used for calculating the volume of water in a

$$
V=\left(\pi\left(\frac{I D}{24}\right)^{2}\right) 7.48 H
$$
}

where $V$ is volume of water in the well, in gallons;

$I D$ is the inside diameter of the well casing, in inches; and

$H$ is the height of the water column in the well, in feet.

${ }^{3}$ The volume of water purged from each well was either about five times the volume of water in the well or the volume of water available until the well was bailed dry.

\section{Hydrology}

Both ground water and surface water are used for rural and urban water supplies in Johnson County, Kansas. Aquifers capable of providing the large yields needed for urban supplies are present only in the Kansas River alluvium. Likewise, the Kansas River is the only river in Johnson County with adequate base flow for urban supplies without the construction of storage reservoirs. Thus, principal surface-water use is along the northern boundary of the county and outside the county in adjacent Wyandotte County. Ground water for stock and domestic purposes may be obtained locally in Johnson County from unconsolidated sediment to a maximum depth below land surface of about 70 to 100 feet and in Pennsylvanianage rocks locally to a depth of about 250 feet. The Pennsylvanian-age rocks that contain ground water of suitable quality for livestock or domestic use consist chiefly of limestone and shale, together with a minor amount of fine-grained sandstone. Yields of wells drilled into the Pennsylvanian-age rocks cannot be accurately predicted but generally are less than 50 gallons per minute (O'Connor, 1971). Probably 90 percent or more of the wells drilled in these rocks have sustained yields less than 10 gallons per minute, and 50 percent or more of the wells probably have sustained yields less than 3 gallons per minute (O’Connor, 1971).

The principal direction of urban growth is from the northeast corner of Johnson County toward the south and west, resulting in increasing distance and a shifting center of usage away from the primary source of water supply along the Kansas River. Wells completed in aquifers at depths of 50 to 250 feet yield water that is generally less suitable for the intended use than wells screened in the shallow aquifers (O'Connor, 1971).

\section{LANDFILL HYDROGEOLOGY}

\section{Geology}

The landfill is located in Pennsylvanian-age rocks. Figure 5 shows a generalized stratigraphic section of the geologic units in the vicinity of the City of Olathe Landfill. Several Pennsylvanian-age formations present at the site (fig. 6, section A-A') have been partially eroded by the two nearby creeks. The only formation that underlies the entire landfill site is the Wyandotte Limestone, exposed along the north landfill boundary. The uppermost bedrock formation at the landfill site, the Stanton Limestone, is thickest along the south landfill boundary (fig. 6 , section B-B'). The formations between the Wyandotte and Stanton Limestones are the Bonner Springs Shale, the Plattsburg Limestone, and the Vilas Shale. These formations crop out along the east landfill boundary and along the unnamed tributary that flows within the landfill boundaries. These outcrops are weathered and covered with soil. The Plattsburg Limestone, Vilas Shale, and 


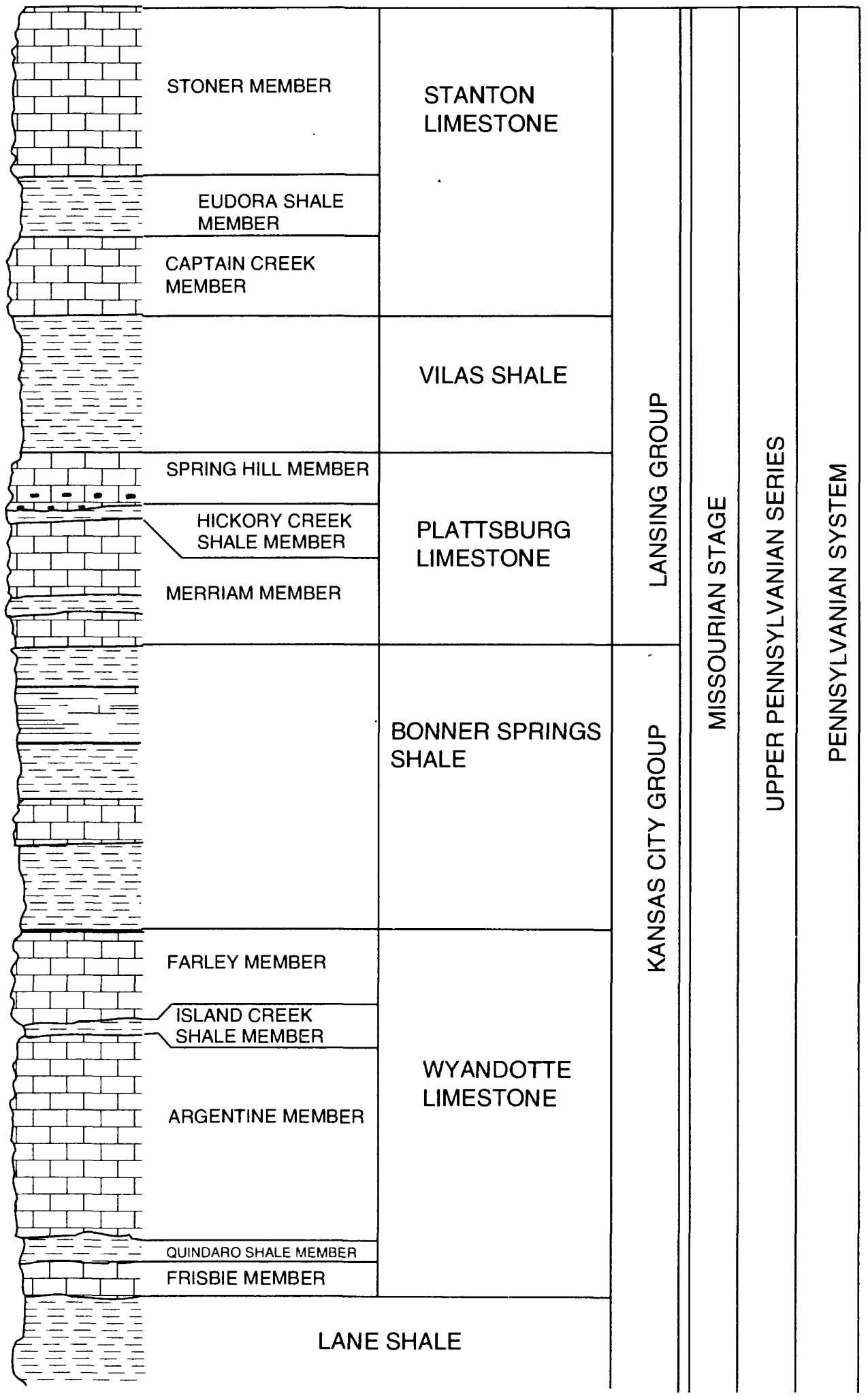

NOT TO SCALE

Figure 5. Generalized stratigraphic section showing formal geologic units in vicinity of the City of Olathe Landfill (data obtained from drill logs in study area). 

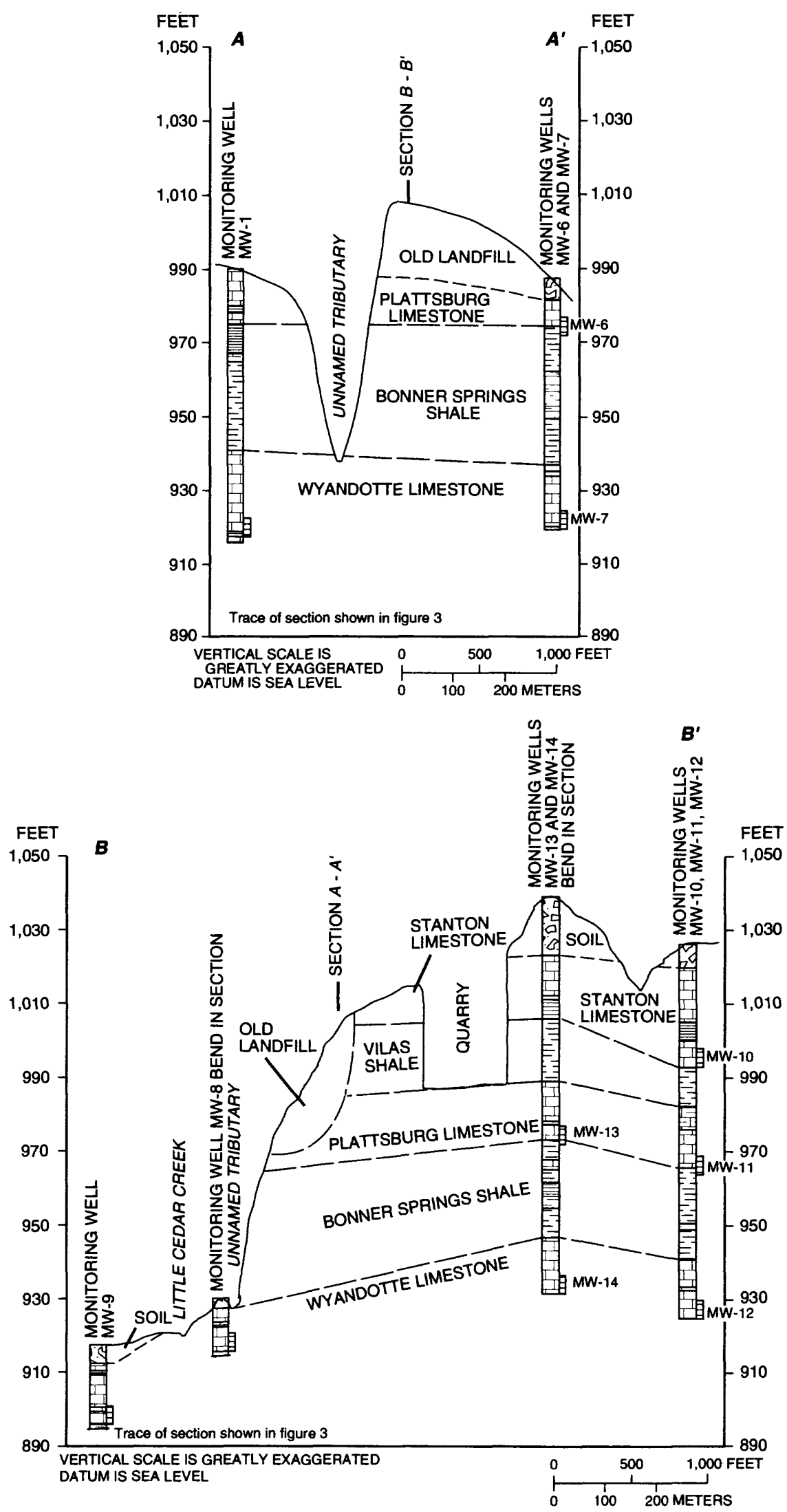

Figure 6. Hydrogeologic sections in vicinity of the City of Olathe Landfill showing lithology and screened intervals. 

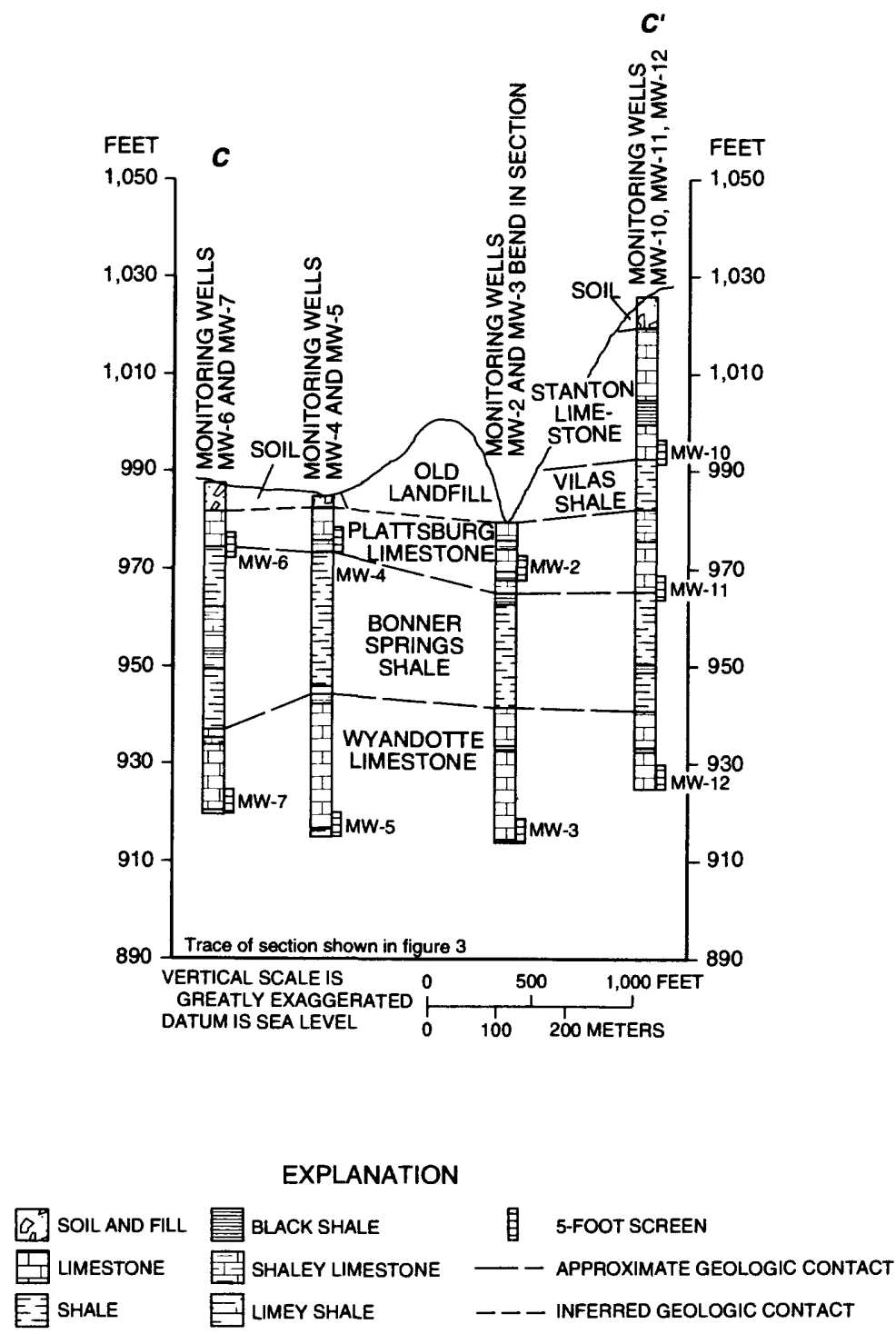

Figure 6. Hydrogeologic sections in vicinity of the City of Olathe Landfill showing lithology and screened intervals-Continued.

Stanton Limestone are exposed in the actively quarried section of the landfill. The following descriptions are based on data collected during installation of monitoring wells and on observations of the exposed section at the quarry site.

The lowest formation described in this report is the Wyandotte Limestone. The formation is not fully penetrated by wells. This formation underlies the entire landfill site and is exposed in the two creeks upstream of the confluence of Little Cedar Creek. At this confluence, vertical joints about $1 / 8$-inch wide trend northwest.

The Bonner Springs Shale varies in thickness from 20 to 40 feet and overlies the Wyandotte Limestone. It also crops out along the two creeks that flow nearby and within the landfill boundaries. The outcrops are exposed in some places but generally are covered with soil. 
The next overlying formation is the Plattsburg Limestone. It varies in thickness from 5 to 15 feet. It is present throughout the landfill except along Little Cedar Creek and its unnamed tributary where it has been eroded. The top of this formation is exposed at the quarry (fig. 6, section B-B'). Here, regularly spaced, vertical fractures are visible trending eastnortheast. Unlike the Wyandotte Limestone the fractures in this formation are very fine, less than 1/32-inch wide, and appear unweathered. The formation at this location appears to dip to the eastnortheast. There is a small pond located directly on top of the northeast quarter of the exposed Plattsburg Limestone (fig. 3). The pond was present during the entire period of the investigation and apparently results from precipitation collecting in an area of relatively impermeable limestone with very fine fractures and an east-northeasterly dip.

The overlying Vilas Shale varies in thickness from 10 to 15 feet. The Vilas Shale has been removed at the quarry site (figs. 3 and 6, section B-B') and is used throughout the landfill as cover material.

The uppermost formation at the landfill, the Stanton Limestone, is present in the central and the southeast quarter of the landfill site. The formation is covered with 0.5 to 15 feet of soil and weathered bedrock. The thickness of this formation varies because its top has been eroded. Along the east landfill boundary about 1,000 feet north of the south boundary, the thickness was found to be about 25 feet (fig. 6 , section B-B'). About 800 feet west and 200 feet north, near the quarry, the thickness is about 15 feet. This formation also has been removed at the quarry site.

The soils onsite and near the landfill consist of silt loam and silty clay loam. In the lower areas near the streams where the land surface is level, the soils consist mostly of silt loam. The slopes along the streams consist of silty clay loam. In the higher areas, where the land surface is relatively level, the soils are silt loam with some silty clay loam. The thicknesses of these soils, including some weathered bedrock, range from about 0.5 foot on the steeper slopes to about 15 feet on the more level areas. All of the soils are moderately to well drained, and the permeabilities are rated slow to moderate. The soils on the slopes contain small volumes of water, whereas the soils lying on the level areas contain larger volumes of water (U.S. Department of Agriculture, 1979).

Monitoring wells are screened in the Wyandotte Limestone, Plattsburg Limestone, and Stanton
Limestone, (see fig. 6, sections A-A', B-B', C-C'). Monitoring wells MW-1, MW-3, MW-5, MW-7, MW-8, MW-9, MW-12, and MW-14 are completed in the Wyandotte Limestone, and wells MW-2, MW-4, MW-6, MW-11, and MW-13 are screened in the Plattsburg Limestone. Only monitoring well MW-10 is screened in the Stanton Limestone. All of the screens, except in wells MW-3, MW-5, MW-7, and MW-12, were installed so that the bottom was set into the shale below the limestone aquifer. This procedure ensured that the well fully penetrated the aquifer. The bottom 5 feet of annular space around the well screen, plus an additional 5 feet above the screen, were filled with sand.

\section{Hydrology}

All of the surface-water runoff from the landfill site flows into Little Cedar Creek or into a small pond located in the quarry. On the east half of the landfill, the runoff flows directly into Little Cedar Creek; on the west half of the landfill, the runoff flows into an unnamed tributary of Little Cedar Creek and then into Little Cedar Creek north of the landfill boundary or into the pond that is near the center of the landfill (fig. 3). During the study, Little Cedar Creek was always flowing, and the unnamed tributary was sometimes flowing. During low flow, Little Cedar Creek flowed above ground until it reached an area near well MW-9, where the water flowed into the fractures in the Wyandotte Limestone and did not flow above ground for about 600 feet. This low-flow condition was observed during August 1992.

Ground water is present in all three limestone formations investigated, although recovery rates (water yields) were slow and varied from well to well after bailing within each aquifer (table 6). One reason for this range of slow recovery rates between wells (recovery times ranging from 1 day to 8 months) is the different size and number of fractures or solution openings in the aquifer near each well. It is not unusual to have one well in an aquifer yield enough water for a small domestic supply, and a nearby well, penetrating the same sequence and thickness of rocks, yield so little water that it is considered a dry well (O'Connor, 1971). The slow recovery rates at most of the wells probably are a result of small hydraulic conductivity of the limestone and slow recharge rates.

The three limestone aquifers vary between confined and unconfined conditions throughout the 


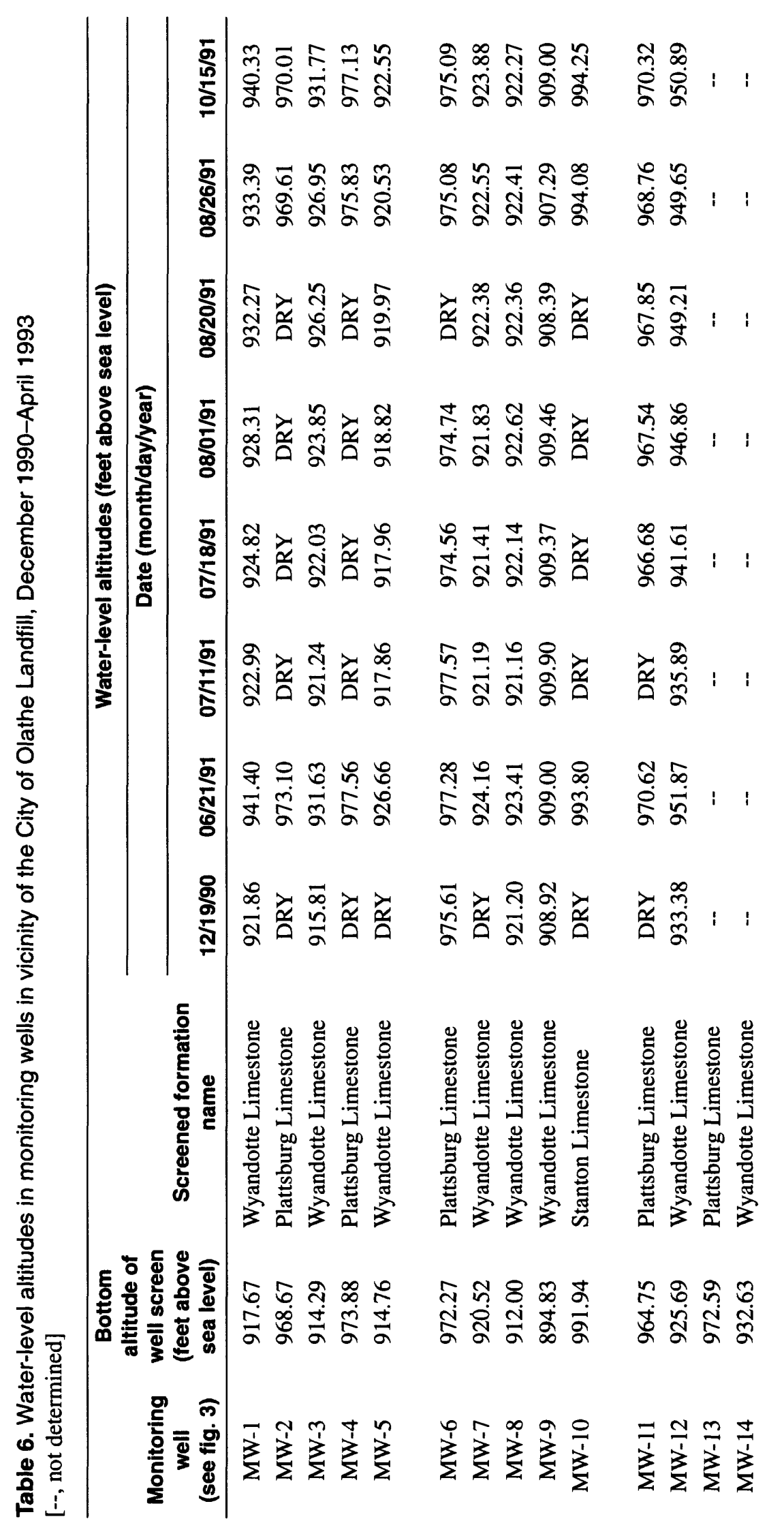


Table 6. Water-level altitudes in monitoring wells in vicinity of the City of Olathe Landfill, December 1990-April 1993-Continued

\begin{tabular}{|c|c|c|c|c|c|c|c|c|}
\hline \multirow{3}{*}{$\begin{array}{l}\text { Monitoring } \\
\text { well } \\
\text { (see fig. 3) }\end{array}$} & \multicolumn{8}{|c|}{ Water-level altitudes (feet above sea level) } \\
\hline & \multicolumn{8}{|c|}{ Date (month/day/year) } \\
\hline & $04 / 03 / 92$ & $06 / 04 / 92$ & $07 / 08 / 92$ & $07 / 31 / 92$ & $08 / 03 / 92$ & $09 / 10 / 92$ & $10 / 13 / 92$ & $04 / 07 / 93$ \\
\hline MW-1 & 949.22 & 949.41 & 949.52 & 949.57 & 920.37 & 928.19 & 935.17 & 948.61 \\
\hline MW-2 & 973.79 & 974.10 & 973.61 & 974.07 & 969.98 & 973.05 & 973.97 & 977.02 \\
\hline MW-3 & 940.24 & 941.64 & 942.69 & 942.53 & 920.49 & 932.99 & 928.64 & 940.34 \\
\hline MW-4 & 979.53 & 978.58 & 975.83 & 975.78 & DRY & DRY & 975.63 & 980.88 \\
\hline MW-5 & 931.46 & 933.94 & 934.46 & 934.66 & DRY & 918.65 & 921.24 & 931.91 \\
\hline MW-6 & 979.77 & 977.07 & 975.38 & 975.78 & 973.45 & 974.64 & 975.55 & 980.85 \\
\hline MW-7 & 929.24 & 930.65 & 931.06 & 931.28 & DRY & 921.53 & 922.27 & 929.05 \\
\hline MW-8 & 923.70 & 923.73 & 923.47 & 923.34 & 918.43 & 923.11 & 923.20 & 924.32 \\
\hline MW-9 & 910.85 & 910.33 & 909.41 & 910.22 & 910.25 & 909.93 & 909.33 & 912.36 \\
\hline MW-10 & 997.96 & 997.02 & 996.50 & 996.50 & 992.74 & 993.61 & 994.19 & 997.42 \\
\hline MW-11 & 970.98 & 971.06 & 971.02 & 970.98 & 965.70 & 968.35 & 970.59 & 970.53 \\
\hline MW-12 & 952.14 & 952.90 & 952.27 & 952.20 & 932.49 & 948.99 & 951.12 & 952.44 \\
\hline MW-13 & -- & -- & -- & -- & DRY & 980.57 & 981.42 & 983.39 \\
\hline MW-14 & -- & -- & -- & -- & -- & DRY & DRY & 943.63 \\
\hline
\end{tabular}

landfill. There are confining layers (less transmissive shale) above and below each aquifer. For an aquifer to be considered confined, the ground water must be confined above and below by confining layers and must be under pressure greater than atmospheric (Todd, 1980). Therefore, the measured hydraulic head (water level) in a well completed in an aquifer under confined conditions will be at a higher altitude than the bottom of the upper confining layer.

Recharge to the three limestone aquifers occurs at different places depending on the relative vertical position of the aquifer. The uppermost aquifer at any given location will be recharged more readily by precipitation than the lower aquifers. The lower aquifers may receive water vertically through the overlying shale during long periods of time. It is possible that the fractures in the limestone may extend into the overlying and underlying shale, allowing for greater vertical flow. Upper and lower aquifers may receive water laterally from outside the study area. Surface-water sources such as infiltration from ponds or creeks also may recharge the limestone aquifers.

Monitoring well MW-10 is screened in the Stanton Limestone. The water-level data and the geologic data collected from well MW-10 indicate that near this well the aquifer is unconfined. Although these data cannot be used to determine the direction of flow through the aquifer, the well can provide background water-quality data pertaining to shallow ground water at the landfill. The direction of flow in this aquifer is not of primary concern because the Stanton Limestone is not present where the landfill waste is disposed. The water-level recovery time for well $\mathrm{MW}-10$ was similar to most of the other wells in other formations, indicating that the aquifer is only slightly transmissive.

Most of the Stanton Limestone within the landfill boundaries is overlain by soil. As mentioned earlier in this report, the landfill soils are silt loam and silty clay loam; therefore, the soil does not allow large quantities of water to infiltrate to the underlying limestone. The small quantity of water that does infiltrate through the soils to the limestone recharges the aquifer.

Ground water flows in the direction of decreasing hydraulic head. Ground-water flow primarily is perpendicular to equipotential lines. In shale and limestone bedrock, directions can vary according to preferential pathways through fractures or solution channels. Close spacing of equipotential lines indicates steep hydraulic gradients, which commonly are due to the low hydraulic conductivity or a local thinning of the host material. In most of the study area, the hydraulic gradient is similar to the land-surface 
gradient. Relatively steep hydraulic gradients (narrow contour spacing) are found primarily in shale, whereas relatively flat gradients (wide contour spacing) are found in limestone because of its greater hydraulic conductivity (Freeze and Cherry, 1979). The hydraulic conductivity of the regional limestone aquifers can be estimated using methods described by Freeze and Cherry (1979, p. 26-30).

There are five wells completed in the Plattsburg Limestone (wells MW-2, MW-4, MW-6, MW-11, and MW-13) (fig. 7A). Shales are confining layers and have much smaller permeabilities than limestone that promote lateral flow. It is possible, however, for vertical flow to occur in the confining layers over an extended period of time. All of the water levels measured in wells screened in the Plattsburg Limestone indicate that the aquifer is unconfined near these wells. On July 31, 1992, the water levels were below the top confining layer (Vilas Shale) in all of the wells screened in the Plattsburg Limestone (well MW-13 was not yet established). Although the aquifer (Plattsburg Limestone) has overlying and underlying confining layers, because the July 31,1992 , water levels were the maximum or near-maximum measured water-level altitudes for the four wells during this study, the aquifer in the Plattsburg Limestone was considered unconfined during the investigation. The Plattsburg Limestone crops out near the wells along the east side of the landfill. Ground water discharges at this outcrop and near well MW-6, a seep flows from the Plattsburg Limestone almost continuously.

The water levels measured on July 31,1992 , in the wells screened in the Plattsburg Limestone indicate that ground water within the aquifer was moving outward, away from the pond located in the quarry (fig. 7A). The top of the Plattsburg Limestone is exposed at this site, and the pond was a local source of recharge for the aquifer. The altitude of the pond was estimated from the altitude of the top of Plattsburg Limestone in wells MW-8 and MW-13.

After bailed dry in June 1991, wells screened in the Plattsburg Limestone required at least 4 months for water-level recovery to near-static conditions. The long recovery time for these wells and the long-term presence of the pond in the quarry probably indicate that the hydraulic conductivity of the Plattsburg Limestone is low.

The same wells were bailed dry again on August 3, 1992. On November 10, 1992, the water levels were not yet recovered (except in well MW-11).
The wells were measured at near-static conditions on April 7, 1993 (fig. 7C). The flow direction was outward from the pond, similar to the conditions found on July 31, 1992.

There are eight wells completed in the Wyandotte Limestone (wells MW-1, MW-3, MW-5, MW-7, MW-8, MW-9, MW-12, and MW-14) (fig. 7B). This formation is similar to the Plattsburg Limestone in that it is confined from above (Bonner Springs Shale) and below (Lane Shale). The thickness of the Wyandotte Limestone at the landfill site was not determined. Most of the monitoring wells in this formation penetrate only the uppermost member of the formation, the Farley Limestone Member. Monitoring wells MW-8 and MW-9 penetrate what is believed to be the Island Creek Shale Member, directly below the Farley Limestone Member.

Water levels indicate that the aquifer in the Wyandotte Limestone was confined near some wells and unconfined near other wells. Ground-water flow in this aquifer, as indicated by the water levels measured on July 31, 1992, and April 7, 1993, was from south to north (figs. $7 B$ and $7 D$ ). The water levels measured in this aquifer during this investigation indicate that the aquifer discharged into Little Cedar Creek and its unnamed tributary. The fractures in some parts of the Wyandotte Limestone are large enough to substantially increase the hydraulic conductivity. For example, the full water-level recovery time, for wells MW-8 and MW-9, after bailing the wells dry, was about 20 days. The full recovery time for well MW-13, under the same conditions, was about 4 months. Water levels in wells MW-1, MW-5, MW-7, and MW-12 required more than 4 months to fully recover under the same conditions. The Wyandotte Limestone probably is recharged by infiltration from precipitation. As shown in figure $7 B$, flow generally is from south to north.

During the summer of 1992, two temporary ponds were created within the landfill boundaries. The city of Olathe constructed a weir near well MW-8 on the unnamed tributary about 100 feet upstream from where it enters Little Cedar Creek. For a few months, the weir restricted the flow of the tributary, creating a small pond. It is not known if the pond had any effect on water levels in well MW-8. At the same time, a small temporary dam was constructed near wells MW-2 and MW-3 to collect surface-water runoff from the landfill before it reached Little Cedar Creek. The water in this pond surrounded the two wells and was 


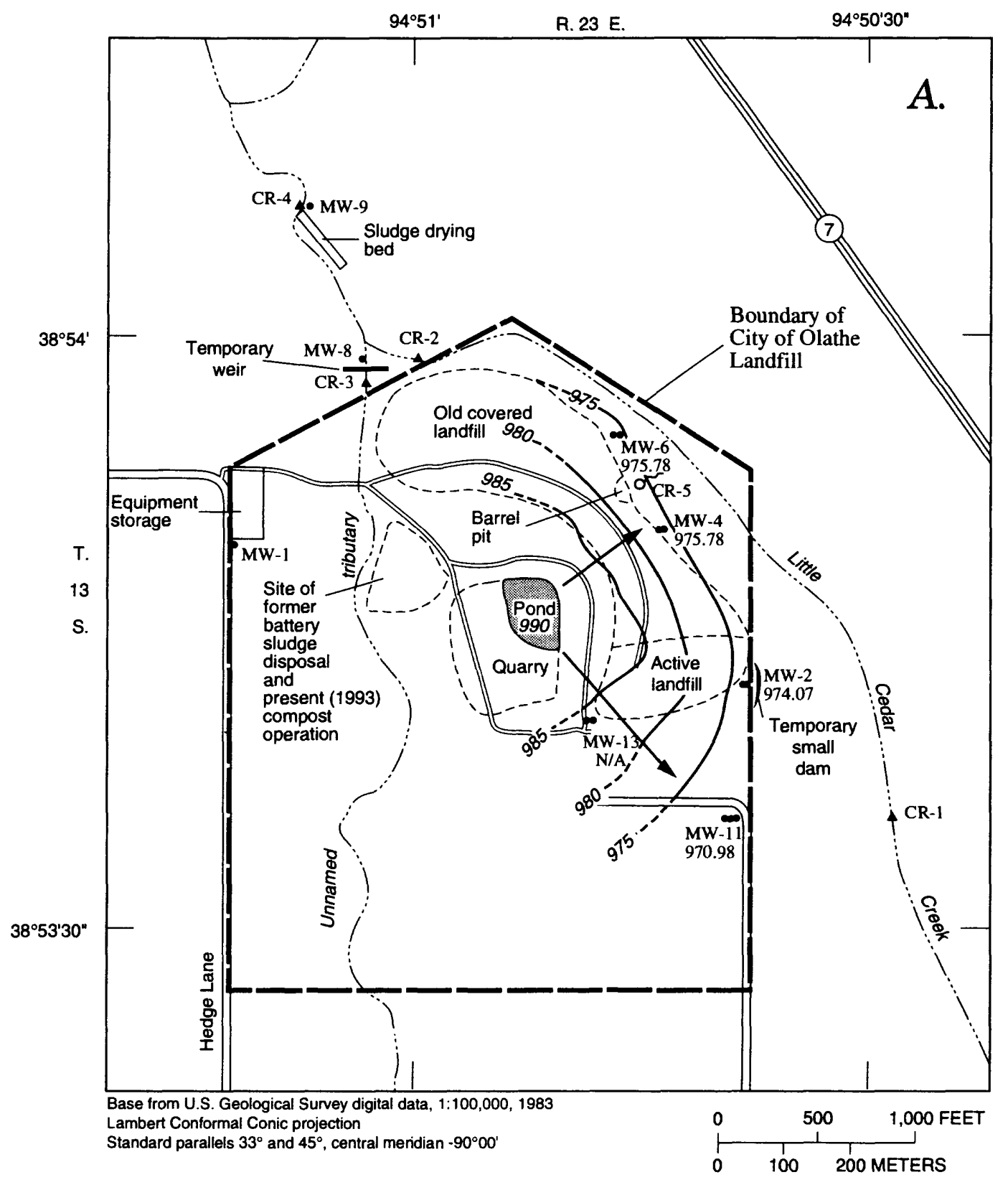

\section{EXPLANATION}

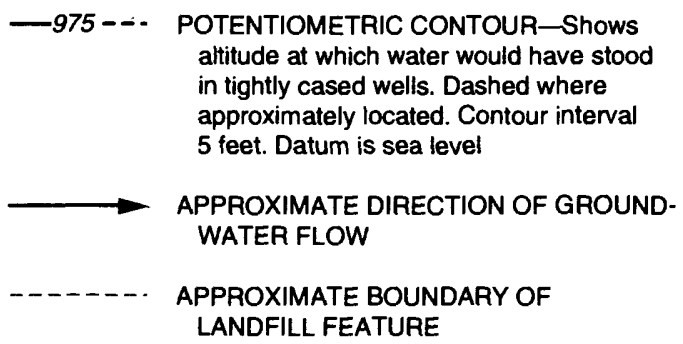
- MW-6 MONITORING WELL AND NUMBER- Lower number is altitude of potentiometric surface, in feet. Datum is sea level
$\triangle$ CR-1 CREEK SAMPLING SITE AND NUMBER
CR-5 SEEP SAMPLING SITE AND NUMBER
N/A WATER LEVEL NOT AVAILABLE

Figure 7. Potentiometric surfaces in aquifers in the $(A)$ Plattsburg Limestone and $(B)$ Wyandotte Limestone on July 31,1992 , and in the $(C)$ Plattsburg Limestone and $(D)$ Wyandotte Limestone on April 7, 1993, City of Olathe Landfill and vicinity. 


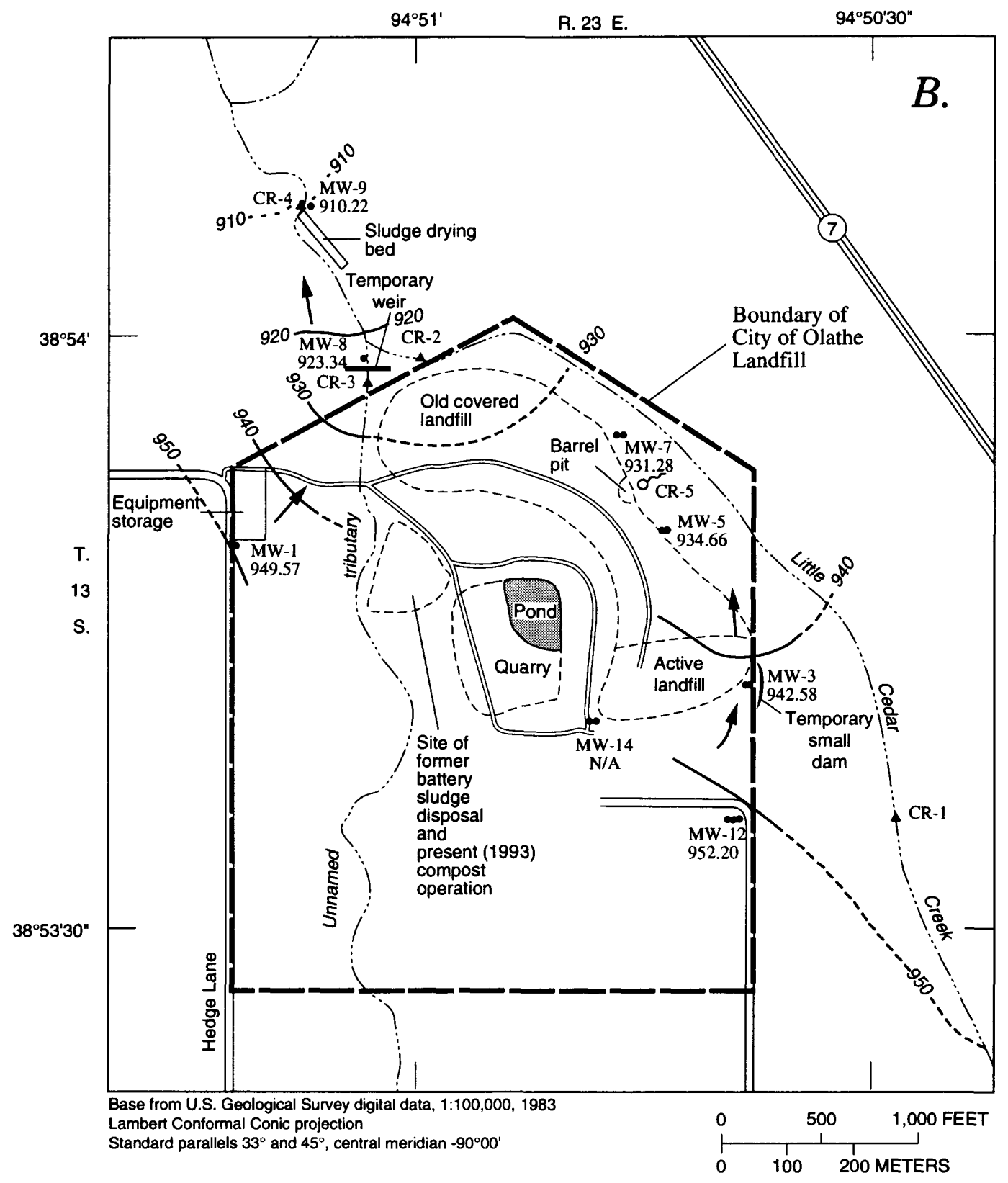

EXPLANATION

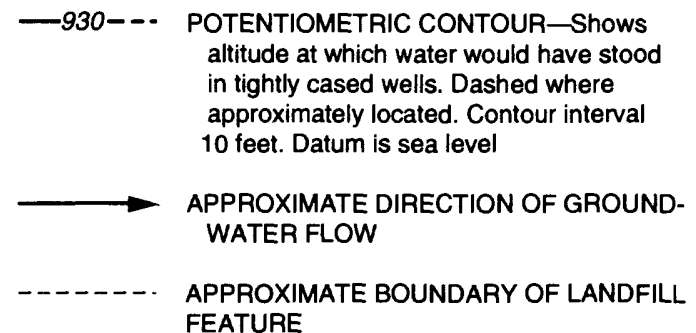
- MW-1 MONITORING WELL AND NUMBER-
949.57 Lower number is altitude of potentiometric surface, in feet. Datum is sea level
^CR-1 CREEK SAMPLING SITE AND NUMBER
CR-5 SEEP SAMPLING SITE AND NUMBER
N/A WATER LEVEL NOT AVAILABLE

Figure 7. Potentiometric surfaces in aquifers in the (A) Plattsburg Limestone and (B) Wyandotte Limestone on July 31,1992 , and in the $(C)$ Plattsburg Limestone and $(D)$ Wyandotte Limestone on April 7, 1993, City of Olathe Landfill and vicinityContinued. 


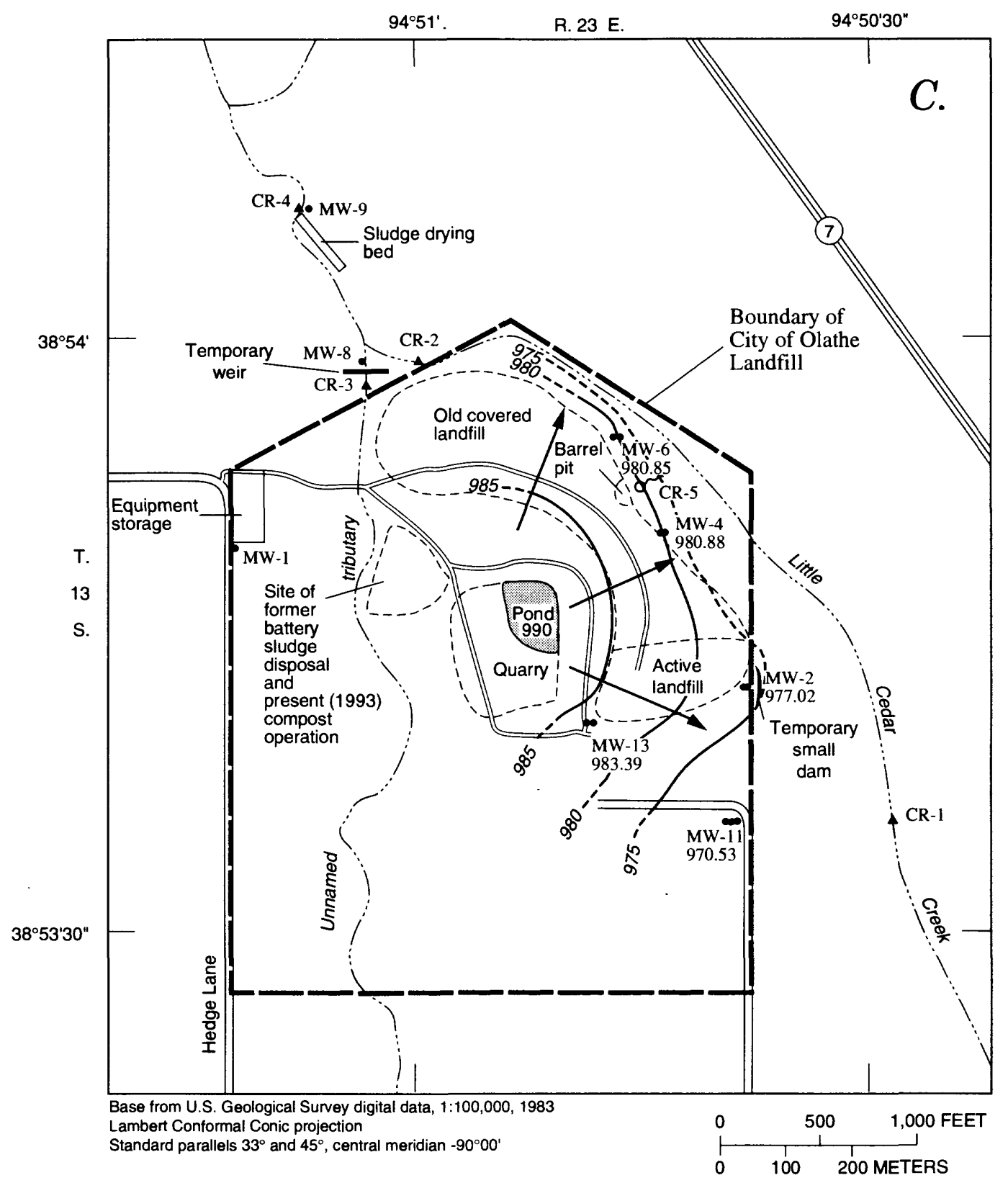

EXPLANATION

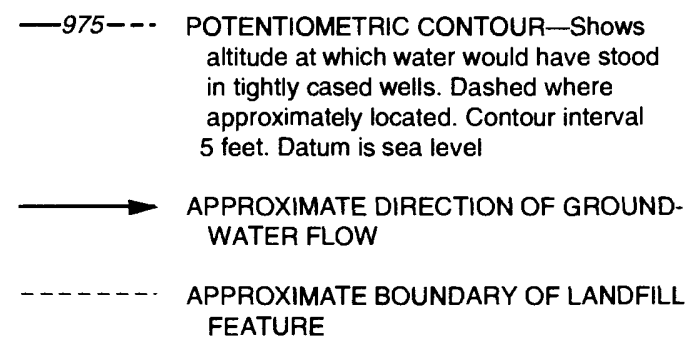

- MW-6 MONITORING WELL AND NUMBER-
L80.85
Lower number is altitude of potentiometric
surface, in feet. Datum is sea level

$\triangle$ CR-1 CREEK SAMPLING SITE AND NUMBER

CR-5 SEEP SAMPLING SITE AND NUMBER

Figure 7. Potentiometric surfaces in aquifers in the $(A)$ Plattsburg Limestone and $(B)$ Wyandotte Limestone on July 31,1992, and in the $(C)$ Plattsburg Limestone and $(D)$ Wyandotte Limestone on April 7, 1993, City of Olathe Landfill and vicinityContinued. 


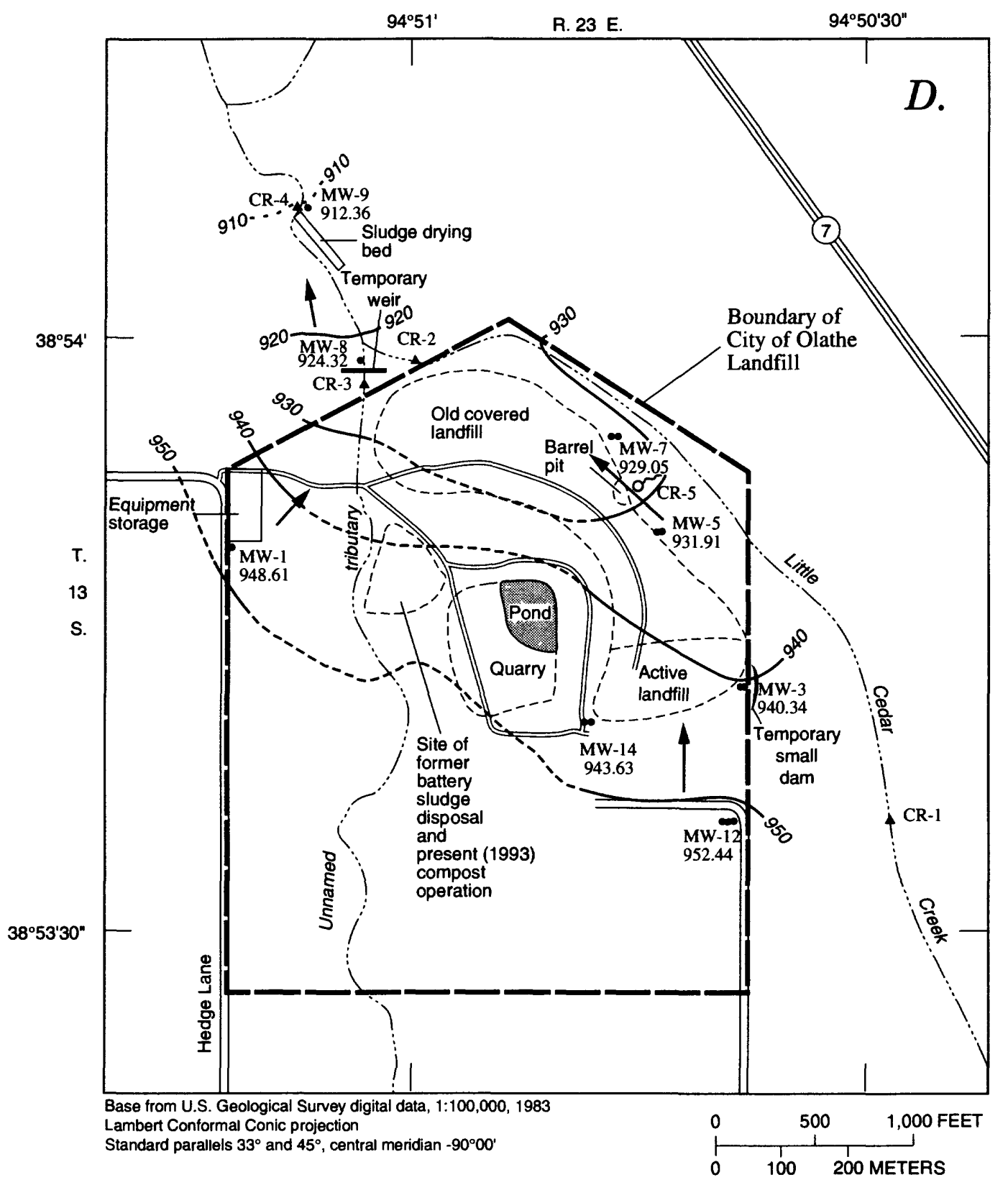

\section{EXPLANATION}
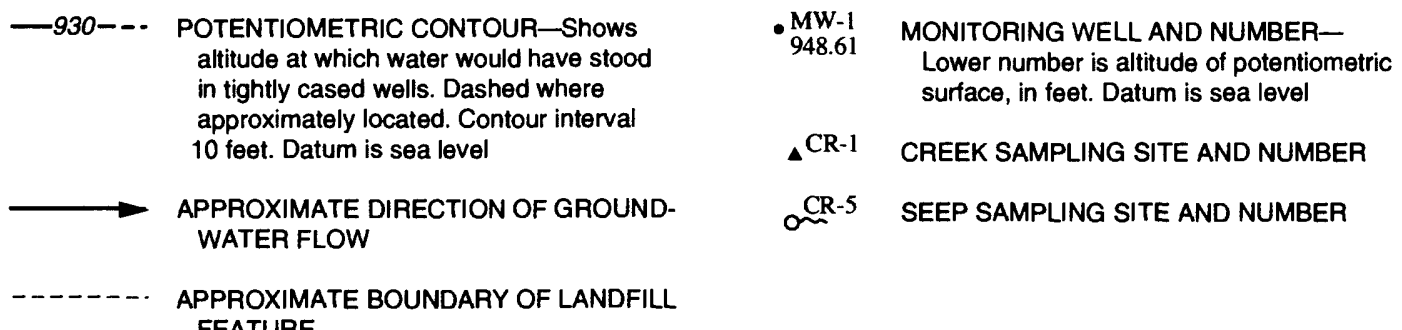

- MW-1 MONITORING WELL AND NUMBERLower number is altitude of potentiometric surface, in feet. Datum is sea level

$\triangle$ CR-1 CREEK SAMPLING SITE AND NUMBER

CR-5 SEEP SAMPLING SITE AND NUMBER FEATURE

Figure 7. Potentiometric surfaces in aquifers in the $(A)$ Plattsburg Limestone and $(B)$ Wyandotte Limestone on July 31,1992 , and in the (C) Plattsburg Limestone and $(D)$ Wyandotte Limestone on April 7, 1993, City of Olathe Landfill and vicinityContinued. 
as deep as 1.5 feet for an undetermined period. Although the tops of the wells were never under water, it is not known if water levels in the wells were affected by the pond.

One of the important aspects of the transport of contaminants through an aquifer is the velocity of ground water. The actual velocity of ground water through an aquifer depends on the hydraulic conductivity, the hydraulic gradient, and the porosity of the aquifer material. Ground water and contaminants may move faster or slower depending on variations in hydraulic conductivity, fractures, and contaminant retardation factors. With a known velocity, transport of contaminants may be predicted.

The velocity is expressed by the equation (Heath, 1983):

$$
\bar{v}=-\frac{K}{n}\left(\frac{d h}{d l}\right)
$$

where,

$$
\begin{aligned}
\bar{v}= & \text { average linear velocity of ground water, in } \\
& \text { feet per day; } \\
K= & \text { hydraulic conductivity, in feet per day; } \\
\frac{d h}{d l}= & \text { hydraulic gradient, in feet per foot; and } \\
\mathrm{n}= & \text { porosity, dimensionless. }
\end{aligned}
$$

At the City of Olathe Landfill, the hydraulic conductivity and porosity of the limestones are not known. The hydraulic gradient can be estimated using the collected data. The range for hydraulic conductivity of limestone is from 0.3 to $3.0 \times 10^{-5}$ foot per day (Freeze and Cherry, 1979, p. 29). The limestone aquifers beneath the landfill probably have hydraulicconductivity values within this range. Hydraulic conductivity can vary depending on the number and size of fractures in the limestone aquifer. The hydraulic gradient can be determined from the potentiometric-surface maps (figs. $7 A$ and $7 B$ ). From the potentiometric-surface map for the Plattsburg Limestone on July 31, 1992 (fig. 7A), the average change in water level beneath the landfill was about 20 feet over a distance of 1,000 feet; therefore, the hydraulic gradient is approximately 0.02 for the Plattsburg Limestone ( $20 \mathrm{feet} / 1,000$ feet). The porosity for limestone ranges from 0 to 0.50 (Freeze and Cherry, 1979, p. 37). To assess the fastest possible path for transport of contaminants, the maximum probable velocity of ground water in these aquifers was calculated. By using equation 1, a maximum hydraulic conductivity of 0.3 foot per day, a hydraulic gradient of 0.02 , and a porosity of 0.01 , the maximum linear velocity for the water through the fractured Plattsburg Limestone was calculated as 0.60 foot per day. By using equation 1 , a maximum hydraulic conductivity of 0.3 , a maximum hydraulic gradient of 0.01 ( $10 \mathrm{feet} / 1,000 \mathrm{feet}$ ), and a porosity of 0.01 , the maximum linear velocity for the water through the fractured Wyandotte Limestone was calculated as 0.30 foot per day.

The actual linear velocity of ground water in these aquifers probably is not larger than the estimated maximum values calculated previously and could be orders of magnitude smaller. If the actual hydraulic conductivity is less than 0.3 or the actual porosity is greater than 0.01 , then the actual velocity would be smaller than the calculated maximum value.

\section{REGIONAL WATER QUALITY}

Between 1944 and 1962, ground-water samples were collected from 47 wells located throughout Johnson County (O'Connor, 1971). These samples were analyzed for major ions and some trace metals. The water in the samples collected from those wells in Johnson County screened in the Wyandotte Limestone was a sodium bicarbonate type. No data were available for samples from any wells in the Plattsburg and Stanton Limestones.

\section{LANDFILL-AREA WATER QUALITY}

Physical properties, inorganic constituents, organic constituents, and concentrations of constituents reported in analyses of water samples from landfill monitoring wells, Little Cedar Creek, the unnamed tributary to Little Cedar Creek, and a seep from the Plattsburg Limestone are listed in tables 7, 8, and 9. Applicable drinking-water regulations for these constituents are included in these tables.

State and Federal drinking-water regulations for public supplies have been established for some chemical constituents that can produce adverse health effects or that affect the aesthetic qualities of water, such as taste, smell, and appearance. The Kansas Notification Level (KNL) (table 9) is the maximum concentration of a constituent in water at which there would be no adverse health effects for lifetime consumption, or, for carcinogens, which would increase the risk of cancer by no more than one in $1,000,000$ (Kansas Department of Health and Environment, 1986). The Kansas Action Level (KAL) 


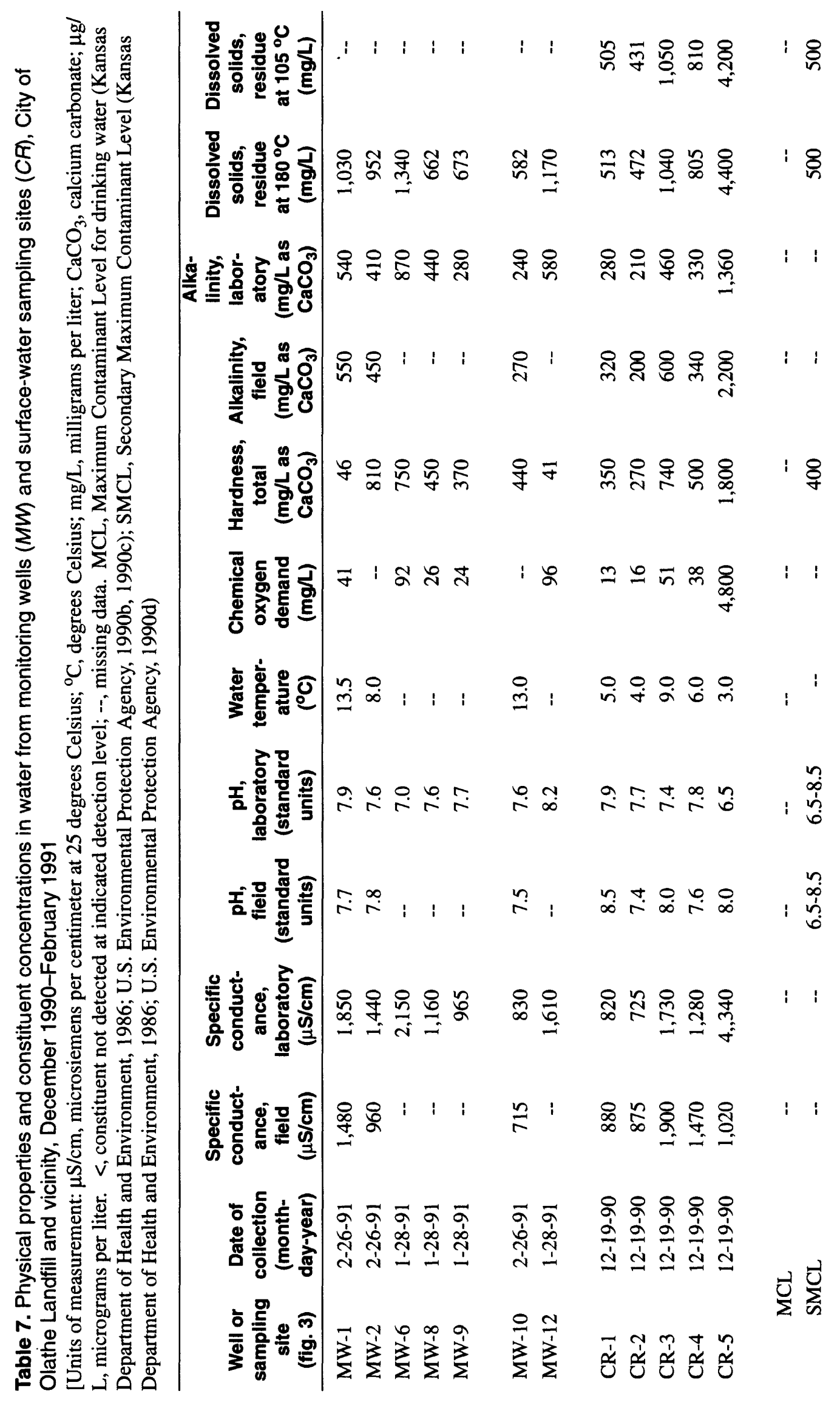




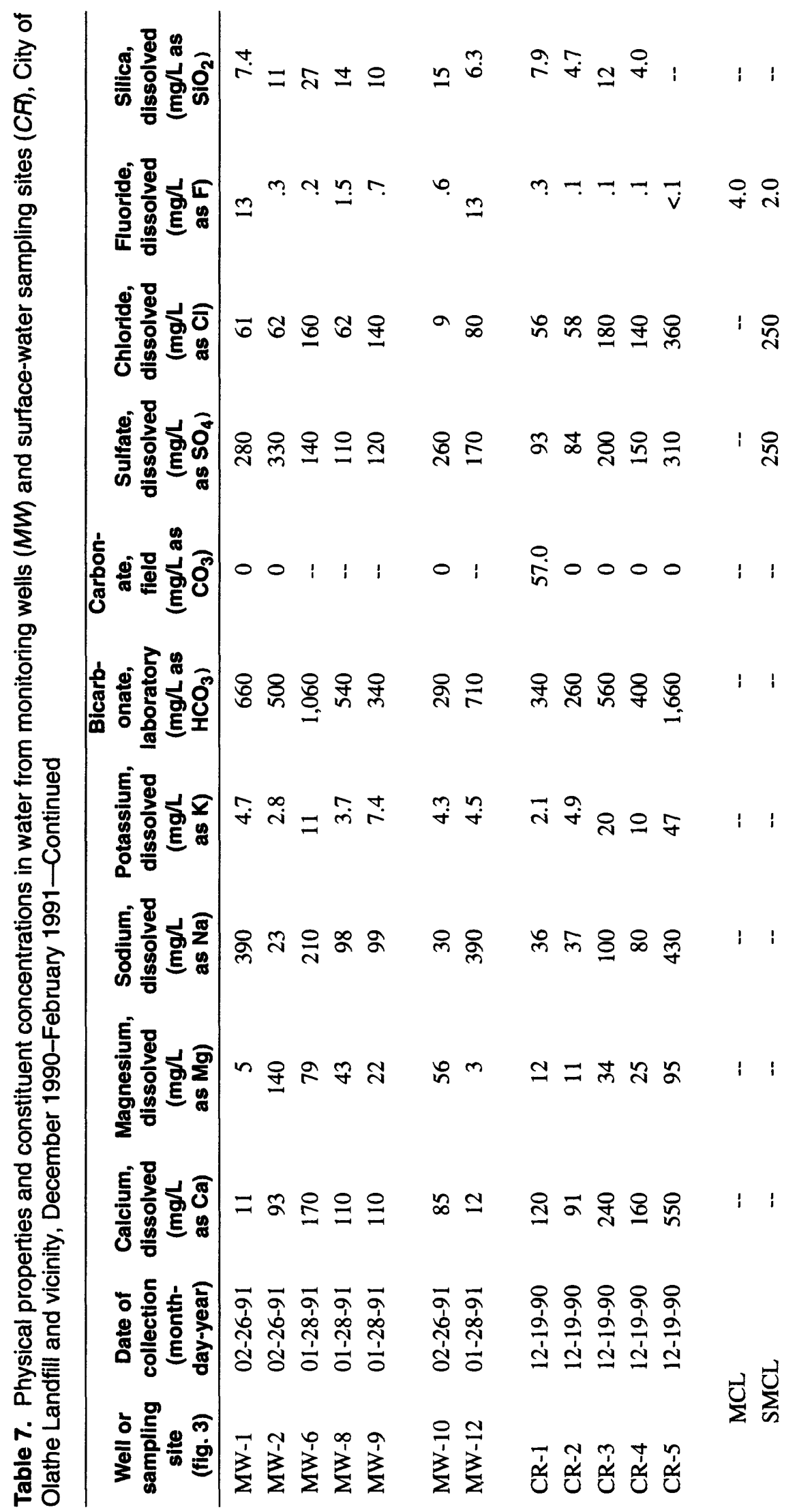




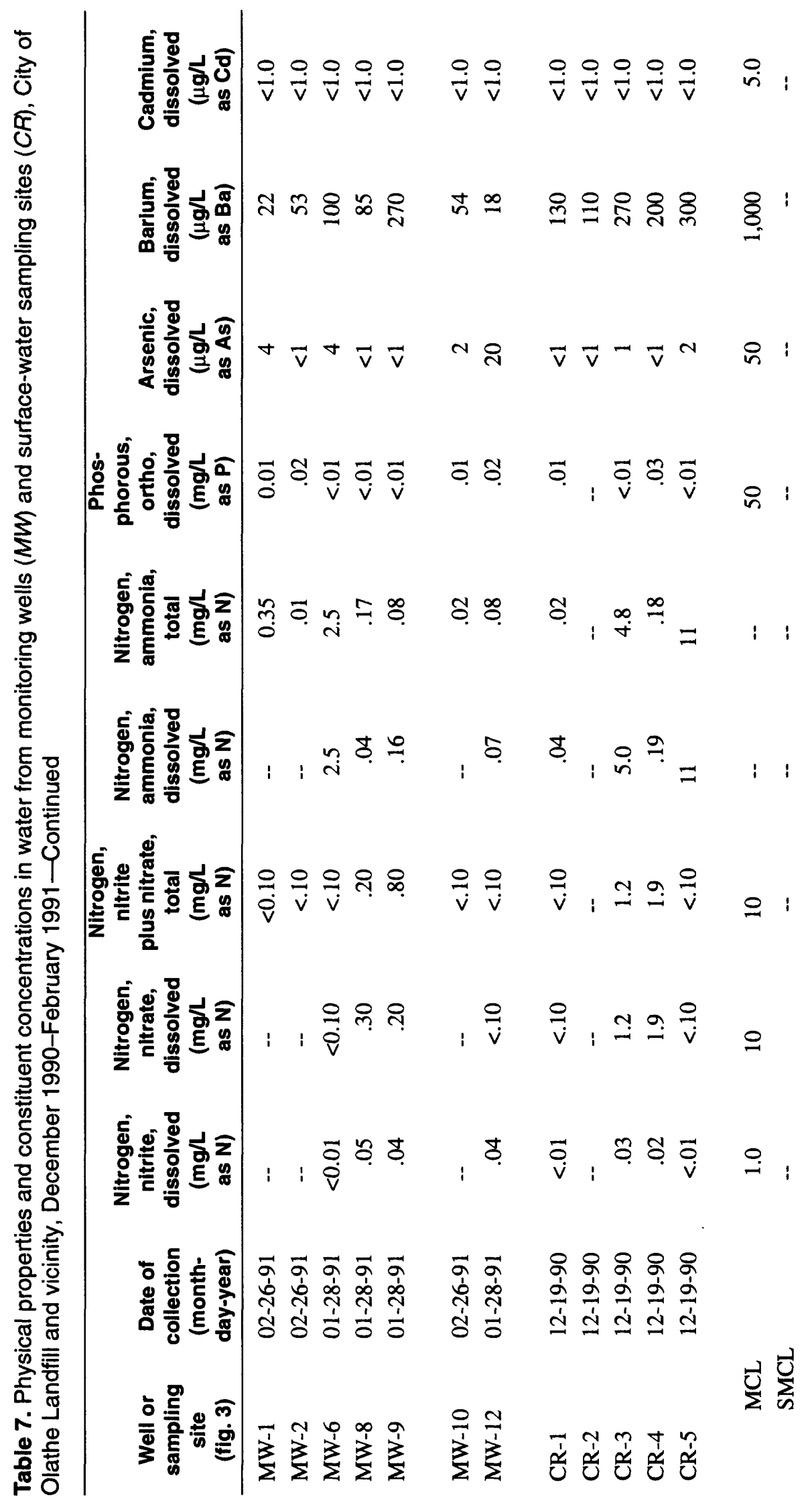




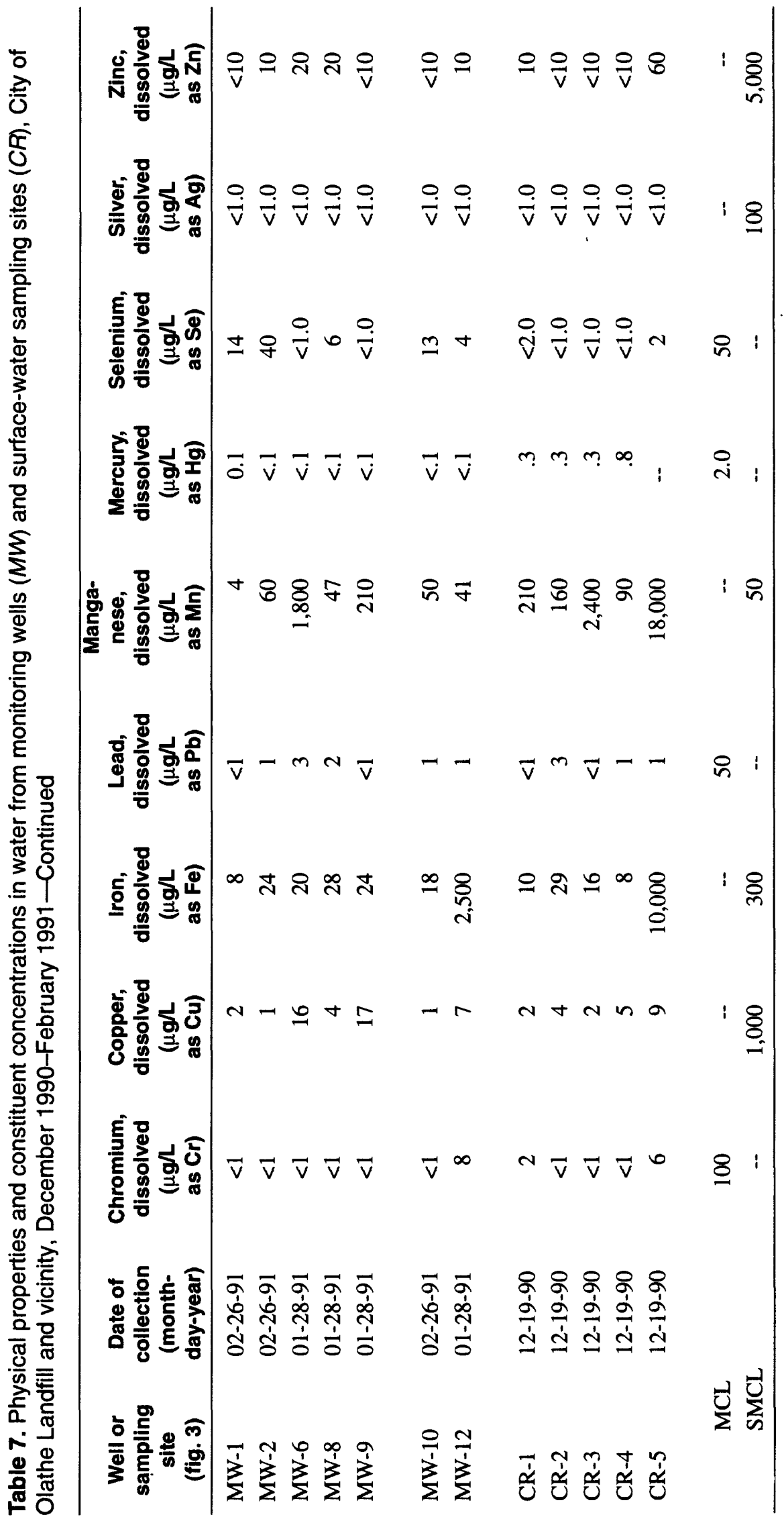


Table 8. Organic compounds analyzed in water samples from monitoring wells and surface-water sampling sites, City of Olathe Landfill and vicinity

\begin{tabular}{|c|c|}
\hline Compound & $\begin{array}{l}\text { Reporting level, in } \\
\text { micrograms per liter }\end{array}$ \\
\hline \multicolumn{2}{|c|}{ Volatile organic compounds } \\
\hline benzene & 0.20 \\
\hline bromoform & .20 \\
\hline carbon tetrachloride & .20 \\
\hline chlorobenzene & .20 \\
\hline chloroethane & .20 \\
\hline 2-chloroethyl vinyl ether & .20 \\
\hline chloroform & .20 \\
\hline chloromethane & .20 \\
\hline dibromochloromethane & .20 \\
\hline 1,2-dibromoethane & .20 \\
\hline dichlorobromomethane & .20 \\
\hline 1,2-dichlorobenzene & .20 \\
\hline 1,3-dichlorobenzene & .20 \\
\hline 1,4-dichlorobenzene & .20 \\
\hline dichlorodifluoromethane & .20 \\
\hline 1,1-dichloroethane & .20 \\
\hline 1,2-dichloroethane & .20 \\
\hline 1,1-dichloroethylene & .20 \\
\hline 1,2-trans-dichloroethene & .20 \\
\hline 1,2-dichloropropane & .20 \\
\hline cis-1,3-dichloropropene & .20 \\
\hline trans-1,3-dichloropropene & .20 \\
\hline 1,3-dichloropropene & .20 \\
\hline ethylbenzene & .20 \\
\hline methyl bromide & .20 \\
\hline methylene chloride & .20 \\
\hline styrene & .20 \\
\hline 1,1,2,2-tetrachloroethane & .20 \\
\hline tetrachloroethylene & .20 \\
\hline toluene & .20 \\
\hline 1,1,1-trichloroethane & .20 \\
\hline 1,1,2-trichloroethane & .20 \\
\hline trichloroethylene & .20 \\
\hline trichlorofluoromethane & .20 \\
\hline vinyl chloride & .20 \\
\hline xylenes, mixed & .20 \\
\hline
\end{tabular}


Table 8. Organic compounds analyzed in water samples from monitoring wells and surface-water sampling sites, City of Olathe Landfill and vicinity-Continued

\begin{tabular}{|c|c|}
\hline Compound & $\begin{array}{l}\text { Reporting level, in } \\
\text { micrograms per liter }\end{array}$ \\
\hline \multicolumn{2}{|c|}{ Semivolatile, acid extractable, compounds } \\
\hline 2-chlorophenol & 5.0 \\
\hline 2,4-dichlorophenol & 5.0 \\
\hline 2,4-dimethylphenol & 5.0 \\
\hline 4,6-dinitro-2-methylphenol & 30 \\
\hline 2,4-dinitrophenol & 20 \\
\hline 2-nitrophenol & 5.0 \\
\hline 4-nitrophenol & 30 \\
\hline pentachlorophenol & 30 \\
\hline phenol & 5.0 \\
\hline 2,4,6-trichlorophenol & 20 \\
\hline 4-chloro-m-cresol & 30 \\
\hline
\end{tabular}

Semivolatile, base-neutral extractable, compounds

$\begin{array}{lr}\text { acenaphthene } & 5.0 \\ \text { acenaphthylene } & 5.0 \\ \text { anthracene } & 5.0 \\ \text { benzo (a) anthracene } & 10 \\ \text { benzo (a) pyrene } & 10\end{array}$

benzo (b) fluoranthene 10

benzo (k) fluoranthene 10

benzo $(\mathrm{g}, \mathrm{h}, \mathrm{i})$ perylene 10

4-bromophenyl phenyl ether $\quad 5.0$

butyl benzyl phthalate $\quad 5.0$

bis (2-chloroethoxy) methane $\quad 5.0$

bis (2-chloroethyl) ether $\quad 5.0$

bis (2-chloroisopropyl) ether $\quad 5.0$

bis (2-ethylhexyl) phthalate $\quad 5.0$

2-chloronaphthalene $\quad 5.0$

4-chlorophenyl phenyl ether $\quad 5.0$

chrysene 10

dibenzo (a,h) anthracene $\quad 10$

1,2-dichlorobenzene $\quad 5.0$

1,3-dichlorobenzene $\quad 5.0$

1,4-dichlorobenzene $\quad 5.0$

diethyl phthalate $\quad 5.0$

dimethyl phthalate $\quad 5.0$ 
Table 8. Organic compounds analyzed in water samples from monitoring wells and surface-water sampling sites, City of Olathe Landfill and vicinity-Continued

\begin{tabular}{lc}
\hline \multicolumn{1}{c}{ Compound } & \multicolumn{1}{c}{$\begin{array}{c}\text { Reporting level, in } \\
\text { micrograms per liter }\end{array}$} \\
\hline di-n-butyl phthalate & 5.0 \\
2,4-dinitrotoluene & 5.0 \\
2,6-dinitrotoluene & 5.0 \\
di-n-octylphthalate & 10 \\
fluoranthene & 5.0 \\
fluorene & \\
hexachlorobenzene & 5.0 \\
hexachlorobutadiene & 5.0 \\
hexachlorocyclopentadiene & 5.0 \\
hexachloroethane & 5.0 \\
& 5.0 \\
ideno (1,2,3-c,d) pyrene & \\
isophorone & 10 \\
naphthalene & 5.0 \\
nitrobenzene & 5.0 \\
n-nitrosodimethylamine & 5.0 \\
n-nitrosodi-n-propylamine & 5.0 \\
n-nitrosodiphenylamine & \\
phenathrene & 5.0 \\
pyrene & 5.0 \\
1,2,4-trichlorobenzene & 5.0 \\
\hline
\end{tabular}

(table 9) is the concentration above which a constituent could produce adverse health effects after longterm consumption of the water (Kansas Department of Health and Environment, 1986). The Maximum Contaminant Level Goal (MCLG) (table 9) is the concentration of a constituent in drinking water at which there would be no adverse health effects for lifetime consumption of the water (U.S. Environmental Protection Agency, 1990a). The Maximum Contaminant Level (MCL) (tables 7 and 9) is the maximum permissible level of a contaminant in water that may be delivered to a free-flowing outlet of a public-water system (U.S. Environmental Protection Agency, 1990b). The MCL is based on the capacity of the best-available technology to minimize contaminant concentrations in drinking water (U.S. Environmental Protection Agency, 1990b, 1990c). Secondary Maximum Contaminant Levels (SMCL) (table 7) have been established for some constituents that affect the aesthetic qualities of the water (U.S. Environmental Protection Agency, 1990d).
Water samples were collected by the U.S. Geological Survey on December 19, 1990 (sampling sites CR-1, CR-2, CR-3, CR-4, and CR-5), January 28, 1991 (wells MW-6, MW-8, MW-9, and MW-12), and February 26, 1991 (wells MW-1, MW-2, and MW10). The following discussion refers to specific groupings of samples in relation to the hydrogeology-in particular, samples collected upgradient from the landfill and samples collected downgradient from the landfill.

A sample collected from well MW-10 completed in the Stanton Limestone represents background conditions for water percolating into the Plattsburg Limestone. None of the samples collected in the Plattsburg Limestone represent upgradient conditions within that formation. Samples collected from wells MW-2 and MW-6 represent downgradient waterquality conditions in the Plattsburg Limestone. Samples from wells MW-1 and MW-12 represent the water-quality conditions in the Wyandotte Limestone 


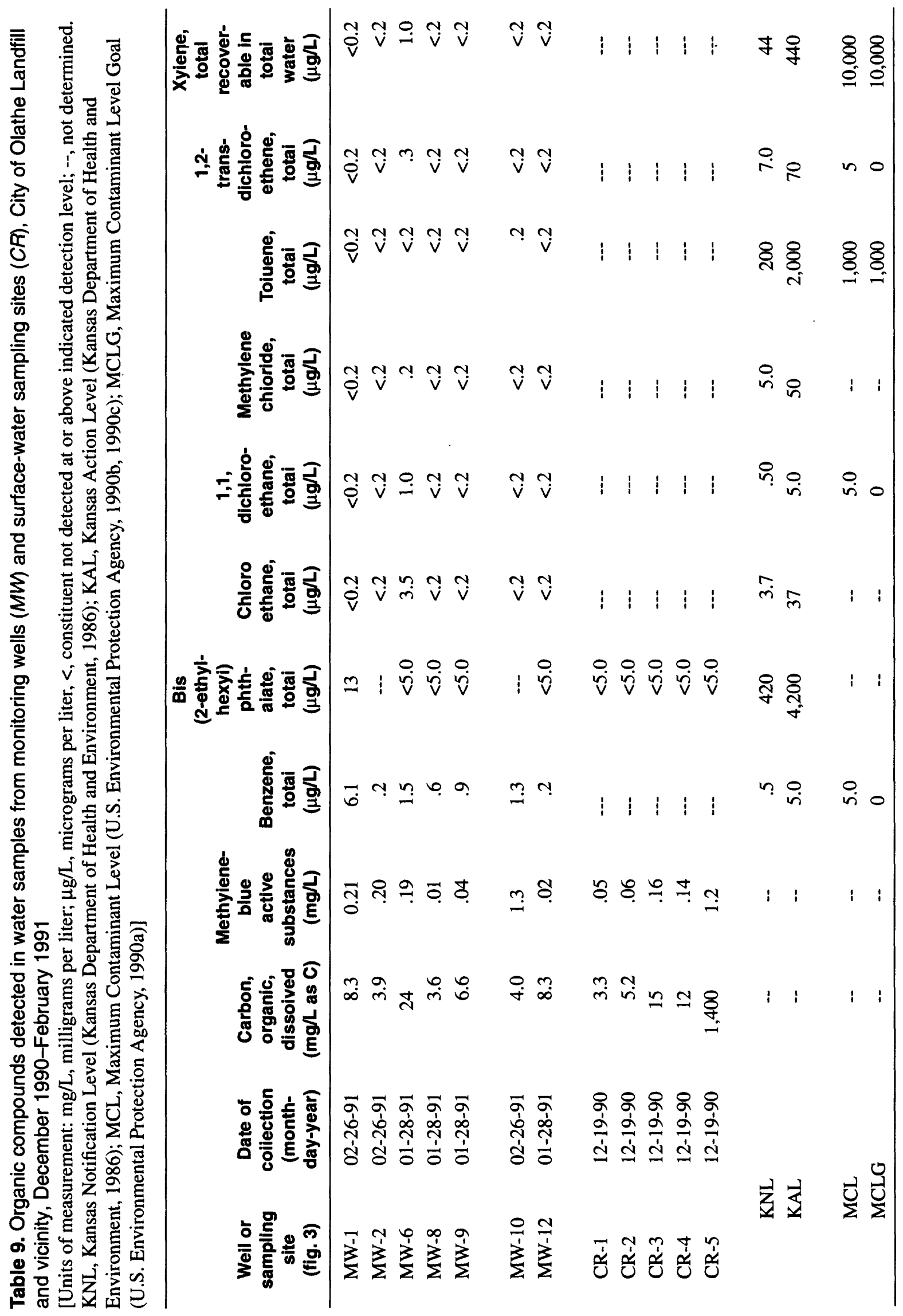


upgradient from the landfill. The downgradient samples from this formation were collected from wells MW-8 and MW-9. A surface-water sampling site upstream of the landfill, site CR-1, on Little Cedar Creek represents the background (upstream) waterquality conditions of the creek. Surface-water samples from sites CR-2, CR-3, and CR-4 were collected downstream of the landfill on Little Cedar Creek and its unnamed tributary and represent the downgradient water-quality conditions of the two creeks. Sampling site CR-2 represents conditions in Little Cedar Creek before the confluence with the unnamed tributary, site CR-3 represents the unnamed tributary conditions before it flows into Little Cedar Creek, and site CR-4 represents a mix from both creeks. Surface-water sampling site CR-5 is a seep on the east side of the landfill directly downgradient of the barrel pit, near well MW-6 (fig. 3). The sample from this seep represents water-quality conditions in the Plattsburg Limestone, immediately downgradient of the landfill. The water-quality analyses for these samples are presented in tables 7 and 9.

Four water types were found in the vicinity of the landfill as shown in figure 8 . The figure indicates major-ion concentrations in milliequivalents per liter plotted on modified Stiff (1951) diagrams. The water types found in water samples from each of the three limestone formations varied from formation to formation. In the sample from monitoring well MW-10 screened in the Stanton Limestone, the water was a calcium magnesium bicarbonate type. The water in a sample from monitoring well MW-2, screened in the Plattsburg Limestone, was a magnesium bicarbonate type. The sample collected from monitoring well MW-6, also screened in the Plattsburg Limestone, contained sodium bicarbonate type water, very different from the type found in the sample from well MW-2. A sample, from the seep (site CR-5) flowing from the Plattsburg Limestone near well MW-6 had a calcium bicarbonate type of water. Water types of samples collected from wells screened in the Wyandotte Limestone varied greatly from upgradient to downgradient. The sodium bicarbonate water found in samples from the upgradient wells (wells MW-1 and MW-12) is quite different from the calcium bicarbonate type found downgradient of the landfill (wells MW-8 and MW-9). The water types found upgradient of the landfill in the Wyandotte Limestone are identical to the types reported by O'Connor (1971) for the same formation elsewhere in Johnson County.
The water in samples collected at sites on Little Cedar Creek and its unnamed tributary (sampling sites CR-1, CR-2, CR-3, and CR-4) was a calcium bicarbonate type. The concentrations of calcium and bicarbonate in the upstream sample, sampling site CR-1, are approximately one-half that of the concentrations of the same constituents in the downstream samples from sites CR-3 and CR-4.

\section{Physical and Chemical Properties}

Physical and chemical properties determined were specific conductance, $\mathrm{pH}$, temperature, chemical oxygen demand, total hardness (as calcium carbonate), and alkalinity. Specific conductance is also a measure of the ability of water to conduct an electrical current (Freeze and Cherry, 1979). Specific conductance is also an indirect measure of the concentration of dissolved solids in water; an increase in dissolvedsolids concentration gives a proportional increase in specific conductance. Organic compounds in water also may increase the specific conductance. For samples from monitoring wells in the vicinity of the City of the Olathe Landfill, specific conductance measured in the laboratory ranged from $830 \mu \mathrm{S} / \mathrm{cm}$ (microsiemens per centimeter at $25^{\circ} \mathrm{C}$ ) (monitoring well MW-10) to $2,150 \mu \mathrm{S} / \mathrm{cm}$ (monitoring well MW-6) (table 7). The specific conductance measured in the laboratory in water samples from monitoring wells screened in the Stanton Limestone and the Plattsburg Limestone also ranged from $830 \mu \mathrm{S} / \mathrm{cm}$ (monitoring well MW-10), the smallest specific conductance measured, to $2,150 \mu \mathrm{S} / \mathrm{cm}$ (well MW-6), the largest specific conductance measured, increasing in groundwater samples from upgradient to downgradient.

The specific-conductance values measured in the laboratory in water samples from wells screened in the Wyandotte Limestone were 1,850 and $1,610 \mu \mathrm{S} / \mathrm{cm}$ in water from upgradient monitoring wells $\mathrm{MW}-1$ and $\mathrm{MW}-12$ and 1,160 and $965 \mu \mathrm{S} / \mathrm{cm}$ in water from downgradient monitoring wells MW-8 and MW-9. Monitoring well MW-8 is 20 feet from the unnamed tributary of Little Cedar Creek, and monitoring well MW-9 is 15 feet from Little Cedar Creek (fig. 3). Given the location of the wells and evidence that the aquifer in this area is fractured, it is probable that the water quality in these wells is affected by the infiltration of nearby surface water. Water in samples from the creeks has a smaller specific conductance than the water from the adjacent aquifer, thereby decreasing the specific conductance of the water in the aquifer when the waters mix. 


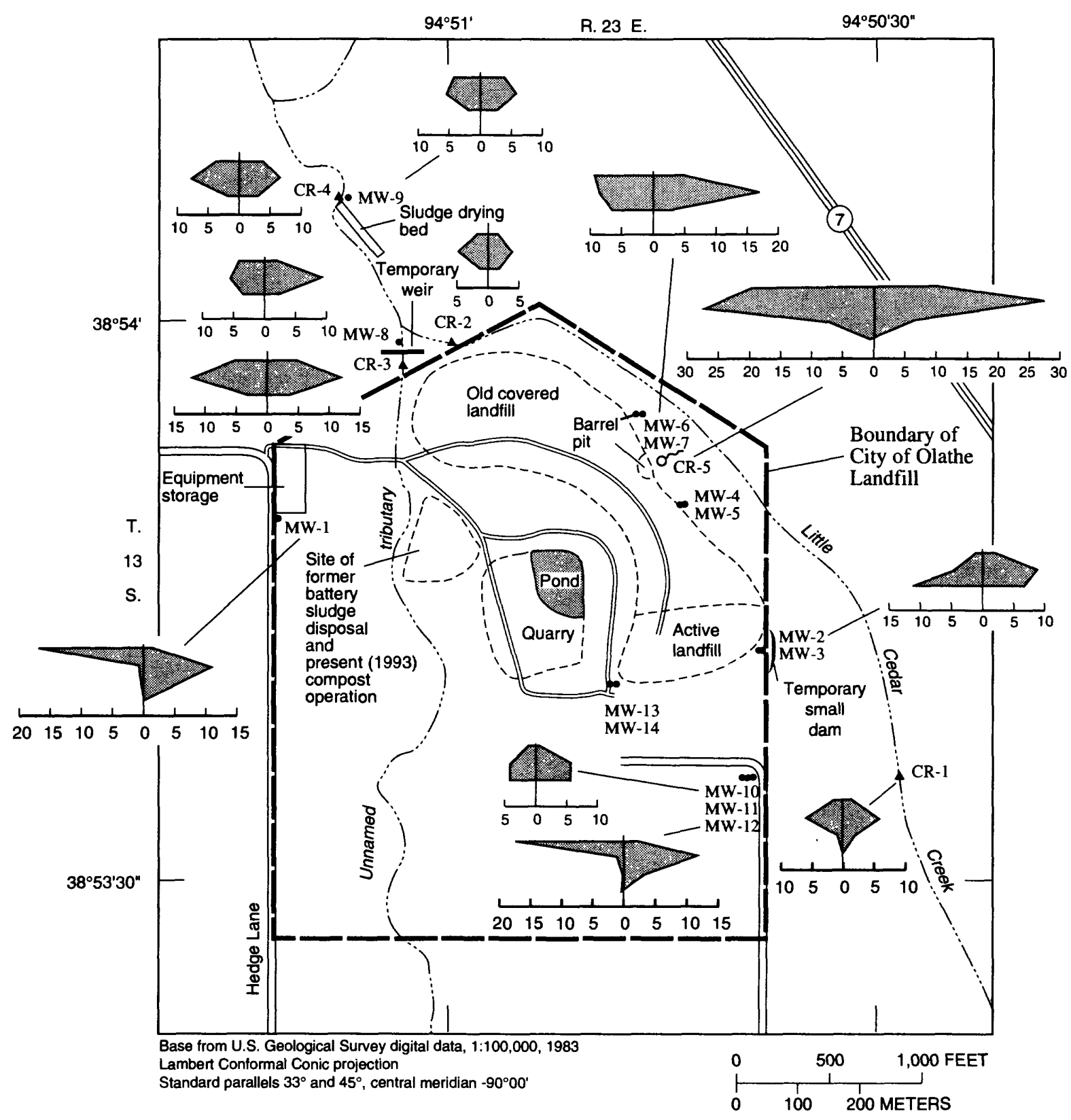

EXPLANATION

WATER TYPE

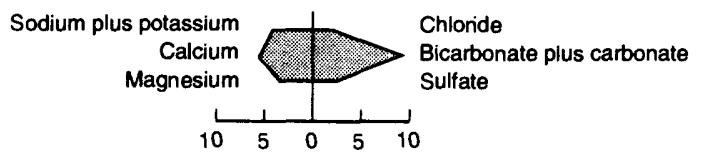

CONCENTRATIONS, IN

MILLIEQUIVALENTS PER LITER

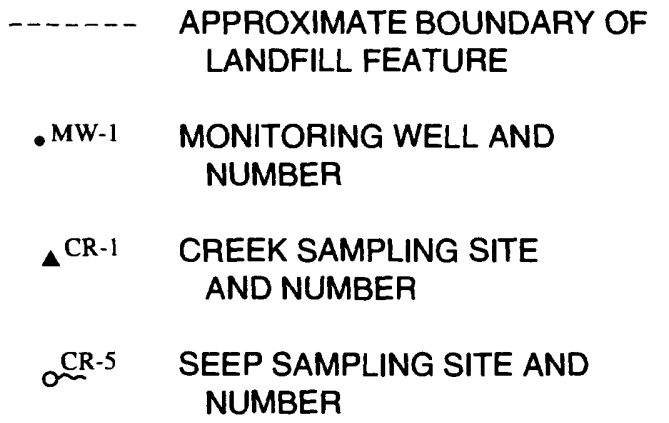

Figure 8. Modified Stiff (1951) diagrams of major-ion concentrations in water samples from monitoring wells and surfacewater sampling sites, December 1990-February 1991. 
The laboratory specific conductance of the surface-water samples ranged from $725 \mu \mathrm{S} / \mathrm{cm}$ (sampling site CR-2) downstream of the landfill to $4,340 \mu \mathrm{S} / \mathrm{cm}$ (sampling site CR-5), also downstream of the landfill. Generally, specific conductance in surface-water samples increased downstream from the landfill.

The $\mathrm{pH}$, a measure of hydrogen-ion activity, ranged from 7.0 (monitoring well $\mathrm{MW}-6$ ) to 8.2 (monitoring well MW-12) in ground-water samples measured in the laboratory, and 6.5 (sampling site CR-5) to 8.5 (sampling site CR-1) in the surface-water and seepage samples measured onsite. The $\mathrm{pH}$ values showed no substantial differences between groundand surface-water samples, except water from downgradient well MW-6 decreased to a laboratory $\mathrm{pH}$ of 7.0 and the seep (site CR-5) had a pH value of 6.5. All $\mathrm{pH}$ values were within the acceptable range for the Kansas and Federal SMCL (table 7).

Ground-water temperatures ranged from $8.0^{\circ} \mathrm{C}$ in water from monitoring well $\mathrm{MW}-2$ to $13.5^{\circ} \mathrm{C}$ in water from monitoring well MW-1. Temperatures of the surface-water samples ranged from $3{ }^{\circ} \mathrm{C}$ at sampling site CR -5 to $9^{\circ} \mathrm{C}$ at sampling site CR-3. The relatively low temperature of water from well MW-2 may indicate the effect of surface-water seepage from the pond discussed earlier in the report.

The COD value from the sample collected at monitoring well MW- 6 was $92 \mathrm{mg} / \mathrm{L}$ (milligrams per liter). COD values of samples from wells in the Wyandotte Limestone ranged from $96 \mathrm{mg} / \mathrm{L}$ (upgradient monitoring well MW-12) to $24 \mathrm{mg} / \mathrm{L}$ (downgradient monitoring well MW-9). COD values of surface-water samples ranged from $13 \mathrm{mg} / \mathrm{L}$ (sampling site CR-1) to $4,800 \mathrm{mg} / \mathrm{L}$ (sampling site CR-5). Values of COD in samples collected from the nearby creeks increased somewhat from upstream (sampling site CR-1) to downstream (sampling sites CR-3 and CR-4). The COD value of the sample from the seep (sampling site CR-5) was about 95 times larger than the COD value detected in the sample collected at site CR-3.

In ground-water samples collected from the Stanton Limestone and the Plattsburg Limestone, total hardness (expressed as $\mathrm{CaCO}_{3}$ ) ranged from $440 \mathrm{mg} / \mathrm{L}$ in water from monitoring well MW-10 (Stanton Limestone) to $810 \mathrm{mg} / \mathrm{L}$ in water from well MW-2 (Plattsburg Limestone). In ground-water samples collected from the Wyandotte Limestone, concentrations ranged from $41 \mathrm{mg} / \mathrm{L}$ (upgradient monitoring well $\mathrm{MW}-12$ ) to
$450 \mathrm{mg} / \mathrm{L}$ (monitoring well MW-8). In surface-water samples, values ranged from $270 \mathrm{mg} / \mathrm{L}$ (sampling site $\mathrm{CR}-2$ ) to $1,800 \mathrm{mg} / \mathrm{L}$ (sampling site CR-5). Water with a hardness of more than $180 \mathrm{mg} / \mathrm{L}\left(\right.$ as $\left.\mathrm{CaCO}_{3}\right)$ is classified as "very hard" (Hem, 1985, p. 159).

Alkalinity concentrations, expressed as $\mathrm{CaCO}_{3}$ and measured in the laboratory, ranged from $240 \mathrm{mg} / \mathrm{L}$ (monitoring well MW-10) to $870 \mathrm{mg} / \mathrm{L}$ (monitoring well MW-6) in water samples collected from the Stanton and Plattsburg Limestones. Surface-water samples ranged from $210 \mathrm{mg} / \mathrm{L}$ (sampling site CR-2) to $1,360 \mathrm{mg} / \mathrm{L}$ (sampling site CR-5). Spatial distributions of alkalinity concentrations are similar to values previously described for specific conductance in that alkalinity values are largest for the seep (sampling site CR-5) and well MW-6 immediately downgradient of the landfill.

\section{Dissolved Solids and Major lons}

Concentrations of dissolved solids, measured by the amount of residue after evaporation of a groundwater sample at 105 and $180^{\circ} \mathrm{C}$, for ground-water samples collected from the Stanton and Plattsburg Limestones, ranged from $582 \mathrm{mg} / \mathrm{L}$ (monitoring well MW-10 screened in the Stanton Limestone) to $1,340 \mathrm{mg} / \mathrm{L}$ (monitoring well MW-6 screened in the Plattsburg Limestone) (fig. 9). Ground water upgradient of the landfill in the Wyandotte Limestone (samples from monitoring wells MW-1 and MW-12) had dissolved-solids concentrations of 1,030 and $1,170 \mathrm{mg} / \mathrm{L}$, respectively, exceeding the Kansas and Federal SMCL of $500 \mathrm{mg} / \mathrm{L}$. The samples collected from the Wyandotte Limestone have twice the dissolved-solids concentrations upgradient of the landfill as downgradient. The concentrations in water from wells MW-1 and MW-12 were large and very similar to the earlier reported values for dissolvedsolids concentrations in the Wyandotte Limestone elsewhere in Johnson County (O'Connor, 1971). Downgradient samples from monitoring wells screened in the Wyandotte Limestone, wells MW-8 and MW-9, had dissolved-solids concentrations of 662 and $673 \mathrm{mg} / \mathrm{L}$, respectively. Dissolved-solid concentrations in the creek samples ranged from 472 to $4,400 \mathrm{mg} / \mathrm{L}$ in the downstream samples (sampling sites CR-2 and CR-5, respectively).

Water samples were analyzed for dissolved major cations, including calcium, magnesium, sodium, and potassium, and for dissolved major anions, including 


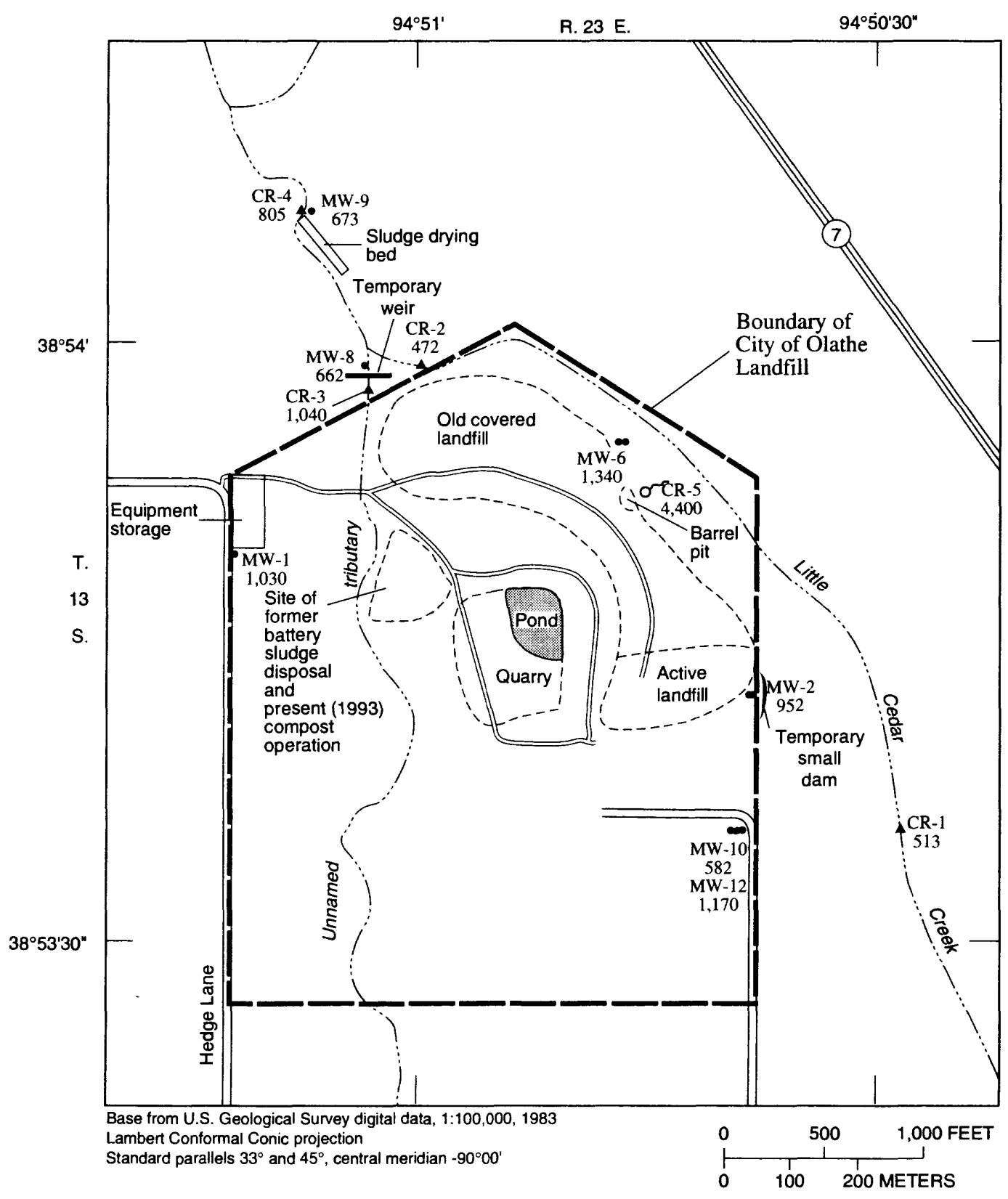

\section{EXPLANATION}

\section{APPROXIMATE BOUNDARY OF LANDFILL FEATURE \\ - MW-1 MONITORING WELL AND NUMBER-Lower number is dissolved-solids concentration, in milligrams per liter \\ - ${ }_{513}^{\text {CR-1 }}$ CREEK SAMPLING SITE AND NUMBER-Lower number is dissolved-solids concentration, in milligrams per liter \\ $\delta$ CR-5 SEEP SAMPLING SITE AND MUNBER-Lower number is dissolved-solids concentration, in milligrams per liter}

Figure 9. Distribution of dissolved-solids concentrations in water in vicinity of the City of Olathe Landfill, December 1990-February 1991. 
bicarbonate (computed from laboratory-determined alkalinity as shown in table 7), sulfate, and chloride. The two samples from the Plattsburg Limestone (wells MW-2, MW-6) had some of the largest concentrations of major ions of all of the ground-water samples. The sample from well MW-2 had a particularly large concentration of magnesium $(140 \mathrm{mg} / \mathrm{L})$, and the sample from well MW-6 had large concentrations of calcium (170 mg/L), magnesium (79 mg/L), and sodium $(210 \mathrm{mg} / \mathrm{L})$. Samples from upgradient wells MW-1 and MW-12 had large concentrations of sodium and bicarbonate. The two ground-water samples collected downgradient of the landfill (wells MW-8 and MW-9) are similar to the surface-water sample collected at site CR-4. The three downstream surfacewater sampling sites (sites CR-3, CR-4, and CR-5) had larger bicarbonate concentrations than the sampling site upstream of the landfill (site CR-1). The sample collected at the seep (site CR-5) had the largest concentrations of calcium $(550 \mathrm{mg} / \mathrm{L})$ and bicarbonate $(1,760 \mathrm{mg} / \mathrm{L})$ of all the samples collected. Dominance of major ions locally could indicate (1) ion exchange as water moves through clay-rich parts of the unconsolidated deposits, (2) flow of water through the shale, or (3) effects of human activity.

The Kansas and Federal SMCL of $250 \mathrm{mg} / \mathrm{L}$ was exceeded for sulfate in samples from wells MW-1, MW-2, and MW-10 and in the sample from surfacewater site CR-5. The Kansas and Federal SMCL of $250 \mathrm{mg} / \mathrm{L}$ also was exceeded for chloride in the surface-water sample from site CR-5.

\section{Nutrients}

Water samples were analyzed for dissolved and total concentrations of nutrients, including nitrite, nitrate, nitrite plus nitrate (all expressed as milligrams per liter as nitrogen), ammonia, and orthophosphorus. Dissolved nitrite concentrations ranged from less than 0.01 to $0.05 \mathrm{mg} / \mathrm{L}$ in water samples at and near the landfill. Dissolved nitrate was detected at concentrations of less than 0.10 to $1.9 \mathrm{mg} / \mathrm{L}$. None of the concentrations exceeded the State and Federal MCL of $10 \mathrm{mg} / \mathrm{L}$.

Concentrations of ammonia in samples collected from locations downgradient of the landfill are larger than the concentrations found in upgradient samples. Dissolved ammonia was detected in all samples for which it was analyzed, including a concentration of $0.07 \mathrm{mg} / \mathrm{L}$ from upgradient monitoring well $\mathrm{MW}-12$ and $0.04 \mathrm{mg} / \mathrm{L}$ from upstream surface-water site CR-1. Concentrations of dissolved ammonia in samples collected at sites downgradient of the landfill, well MW-6 and sampling sites CR-3 and CR-5, were 2.5, 5.0 , and $11 \mathrm{mg} / \mathrm{L}$, respectively. Samples collected farther downgradient of the landfill had decreased concentrations of dissolved ammonia. Water from well MW-9 and sampling site CR-4 had concentrations of 0.16 and $0.19 \mathrm{mg} / \mathrm{L}$, respectively.

The presence of nitrate or ammonia in water can be an indicator of whether oxidizing or reducing conditions prevail. Under reducing conditions, typical of landfill leachate, nitrate may be reduced to ammonia. This effect was observed at the Geary County, Kansas, landfill (Myers and Bigsby, 1989). At the City of Olathe Landfill, the largest ammonia concentrations were in water samples from well MW-6 and sampling sites CR-3 and CR-5. These sites are located within and near the landfill boundaries and may indicate reducing conditions in the flow system.

Orthophosphorus concentrations did not vary spatially from upgradient to downgradient wells. The constituent was not detected (less than $0.01 \mathrm{mg} / \mathrm{L}$ ) in samples from wells MW-6, MW-8, and MW-9 and sampling sites CR-3 and CR-5. Orthophosphorus was detected at $0.01 \mathrm{mg} / \mathrm{L}$ in samples from wells $\mathrm{MW}-1$ and MW-10 and sampling site CR-1. Concentrations of $0.02 \mathrm{mg} / \mathrm{L}$ were determined in samples collected from wells MW-2 and MW-12. In water from sampling site CR-4, the concentration was $0.03 \mathrm{mg} / \mathrm{L}$.

\section{Trace Elements}

Dissolved trace elements analyzed in water samples were arsenic, barium, cadmium, chromium, copper, iron, lead, manganese, mercury, selenium, silver, and zinc. All trace-element concentrations were measured in micrograms per liter. Arsenic was detected in water samples from four monitoring wells (wells MW-1, MW-6, MW-10, and MW-12) and two surface-water sampling sites (sites CR-3 and CR-5). None of the concentrations exceeded the State or Federal MCL of $50 \mu \mathrm{g} / \mathrm{L}$. Barium concentrations ranged from $18 \mu \mathrm{g} / \mathrm{L}$ in water from upgradient monitoring well MW-12 to $300 \mu \mathrm{g} / \mathrm{L}$ in a sample from downgradient sampling site CR-5. None of the concentrations exceeded the State and Federal MCL for barium $(1,000 \mu \mathrm{g} / \mathrm{L}$, table 7$)$. Iron and manganese concentrations in some water samples approached or exceeded State and Federal MCLs and SMCLs. Iron 
concentrations (fig. 10) in water samples from upgradient monitoring well MW-12 and downgradient sampling site CR-5 were 2,500 and $10,000 \mu \mathrm{g} / \mathrm{L}$, respectively, which were the only samples exceeding the State and Federal SMCL of $300 \mu \mathrm{g} / \mathrm{L}$. Manganese concentrations (fig. 10) in samples collected from monitoring wells MW-2, MW-6, MW-9, and MW-10 and surface-water sampling sites CR-1, CR-2, CR-3, $\mathrm{CR}-4$, and CR-5 ranged from 50 to $18,000 \mu \mathrm{g} / \mathrm{L}$, equalling or exceeding the $50-\mu \mathrm{g} / \mathrm{L}$ State and Federal SMCL. No samples from monitoring wells or surfacewater sampling sites had concentrations of selenium greater than the State and Federal MCL of $50 \mu \mathrm{g} / \mathrm{L}$.

Obvious patterns of spatial distributions were apparent for concentrations of barium, iron, and manganese. These spatial distributions are similar to the distributions of dissolved-solids and ammonia concentrations. The concentrations upgradient of the landfill are much smaller than the concentrations found immediately downgradient of the landfill. Trace-element concentrations farther downgradient were diluted and closer to background concentrations except barium. Concentrations of barium, iron, and manganese in water from wells MW-1 and MW-12 (with the exception of iron in well MW-12) and surface-water sampling site CR-1 were much less than the concentrations detected at immediate downgradient locations (wells MW-2 and MW-6 and surface-water sampling sites CR-3 and CR-5). As water moved to downgradient wells MW-8 and MW-9 and the downgradient surface-water sampling site $\mathrm{CR}-4$, the concentrations decreased with the exception of barium.

\section{Other Inorganic Constituents}

Dissolved-fluoride concentrations were fairly uniform throughout the landfill area, except in the upgradient samples from monitoring wells MW-1 and $\mathrm{MW}-12$. The concentrations of fluoride in these samples were $13 \mathrm{mg} / \mathrm{L}$, exceeding the Kansas and Federal MCL of $4.0 \mathrm{mg} / \mathrm{L}$. These concentrations are similar to levels detected in the Wyandotte Limestone by O'Connor (1971), which were 6.0 and $11.0 \mathrm{mg} / \mathrm{L}$ at two different locations in Johnson County.

Silica concentrations in samples from monitoring wells ranged from $6.3 \mathrm{mg} / \mathrm{L}$ (upgradient Wyandotte Limestone monitoring well MW-12) to $27 \mathrm{mg} / \mathrm{L}$ (downgradient Plattsburg Limestone monitoring well MW-6), and concentrations in surface-water samples ranged from 4.0 (site CR-4) to $12.0 \mathrm{mg} / \mathrm{L}$ (site CR-3).

\section{Organic Compounds}

Water samples from the landfill monitoring wells were analyzed for concentrations of selected organic compounds. Of the organic compounds listed in table 9,10 compounds were detected in water samples (table 9). Each organic compound detected is discussed in the following paragraphs and listed in table 10.

The reporting level is the smallest measured constituent concentration that may be reliably reported using a given analytical method. Detection level is the minimum constituent concentration that can be identified, measured, and reported with confidence that the concentration is larger than zero. The reporting level is set somewhat larger than the detection level because of sample-composition (matrix) effects.

Dissolved-organic-carbon (DOC) concentrations in ground-water samples ranged from 3.6 to $8.3 \mathrm{mg} / \mathrm{L}$, except the sample collected from the Plattsburg Limestone at well MW-6, which had a concentration of $24 \mathrm{mg} / \mathrm{L}$. The DOC concentration detected in the upgradient surface-water sample (site CR-1) was $3.3 \mathrm{mg} / \mathrm{L}$. The surface-water sample collected at site CR-2 also had a small concentration of $5.2 \mathrm{mg} / \mathrm{L}$, but the rest of the surface-water samples had concentrations that equalled or exceeded $12.0 \mathrm{mg} / \mathrm{L}$. The concentration in water from the seep at sampling site CR-5 was almost 100 times larger than the largest concentration in the creek samples. Thurman (1985) reported that typical DOC concentrations in ground water range from 0.2 to $15 \mathrm{mg} / \mathrm{L}$, with a median concentration of $0.7 \mathrm{mg} / \mathrm{L}$. DOC concentrations in surface water usually are larger than in ground water (Thurman, 1985). DOC may be an indicator of organic substances dissolved in water if concentrations are large (greater than $15 \mathrm{mg} / \mathrm{L}$ ). A relatively large concentration of organic compounds would be required to affect the DOC concentration because DOC concentration is reported in milligrams per liter, whereas organic compounds are reported in micrograms per liter.

The analysis for methylene-blue active substances (MBAS) tests for the presence of surfactants, including alkyl benzene sulfonate and linear alkyl sulfonate (Wershaw and others, 1987). These surfactants are common components of detergents. Organic and inorganic compounds may interfere with the 


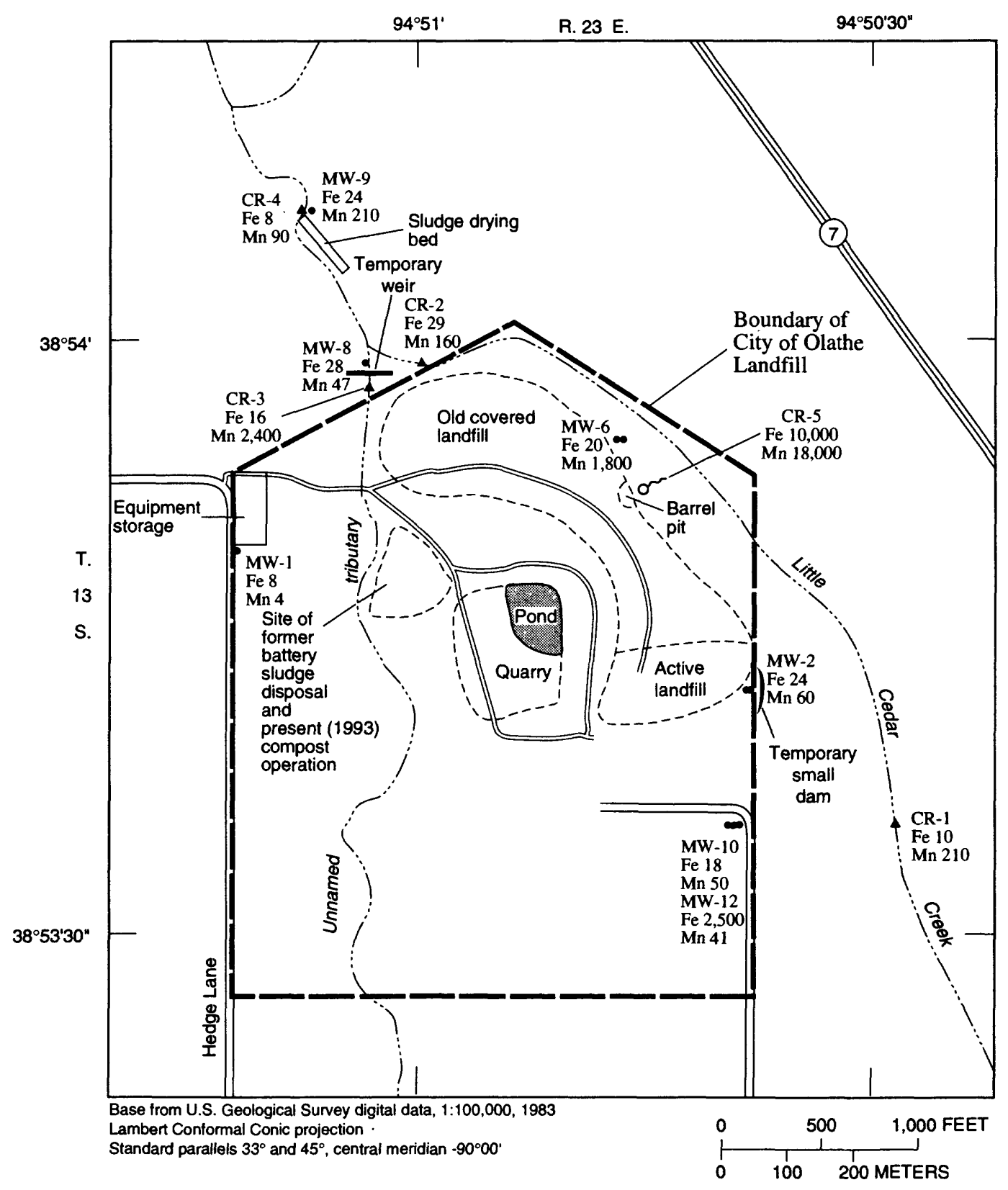

EXPLANATION

\section{APPROXIMATE BOUNDARY OF LANDFILLL FEATURE}

- MW-1 MONITORING WELL AND NUMBER-Second number is

$\mathrm{Fe} 8$ iron $(\mathrm{Fe})$ concentration and third number is manganese $(\mathrm{Mn})$ concentration, in micrograms per liter

$\triangle \mathrm{FR}-1$

Mn 210

CREEK SAMPLING SITE AND NUMBER-Second number is iron (Fe) concentration and third number is manganese (Mn) concentration, in micrograms per liter

CR-5

Fe 10,000

SEEP SAMPLING SITE AND NUMBER-Second number is iron ( $\mathrm{Fe}$ ) concentration and third number is manganese (Mn) concentration, in micrograms per liter

Figure 10. Distribution of iron and manganese concentrations in water in vicinity of the City of Olathe Landfill, December 1990-February 1991. 
Table 10. Organic compounds detected in groundwater samples collected in the vicinity of the City of Olathe Landfill, January and February 1991

\begin{tabular}{ll}
\multicolumn{1}{c}{ Well (fig. 3) } & \multicolumn{1}{c}{ Compounds } \\
\hline MW-1 & Bis(2-ethylhexyl)phthalate \\
MW-6 & Chloroethane \\
& Methylene chloride \\
& 1,1-dichloroethane \\
& 1,2-trans-dichloroethene \\
& 1,1 -dichloroethane \\
& Xylene \\
& \\
& Toluene \\
MW-10 & \\
& Dissolved organic carbon \\
& Methylene-blue active substances \\
& Benzene \\
\hline
\end{tabular}

MBAS analysis giving false readings that are usually too large. For small concentrations of MBAS (less than $0.50 \mathrm{mg} / \mathrm{L}$ ), the interference renders the results unreliable (American Public Health Association, 1976).

Of the MBAS concentrations detected in the ground-water samples, only one exceeded $0.50 \mathrm{mg} / \mathrm{L}$. Water from monitoring well MW-10 had a concentration of $1.3 \mathrm{mg} / \mathrm{L}$ (table 9 ). Only one of the surfacewater samples also had an MBAS concentration greater than $0.50 \mathrm{mg} / \mathrm{L}$. A concentration of $1.2 \mathrm{mg} / \mathrm{L}$ was found in water from sampling site CR-5. The samples from well MW-10 and site CR-5 probably had some MBAS present. Due to the possibility of interference occurring at a concentration of less than $0.50 \mathrm{mg} / \mathrm{L}$, all samples may reflect the interference rather than the true MBAS.

- Benzene was detected in all of the ground-water samples. Surface-water samples were not analyzed for benzene. Concentrations ranged from $0.2 \mu \mathrm{g} / \mathrm{L}$ (well MW-2) to $1.5 \mu \mathrm{g} / \mathrm{L}$ (well MW-6), both in water from the Plattsburg Limestone (fig. 11). In the Wyandotte Limestone, the largest concentration was detected in water from upgradient well MW-1 at $6.1 \mu \mathrm{g} / \mathrm{L}$. The remaining wells had concentrations of $2.0 \mu \mathrm{g} / \mathrm{L}$ or less. The KNL for drinking water of $0.5 \mu \mathrm{g} / \mathrm{L}$ was exceeded in samples collected from all wells except well MW-2. The MCL of $5.0 \mu \mathrm{g} / \mathrm{L}$ was exceeded only in water from well MW-1. Benzene is used as an intermediate in the manufacturing of chemical compounds, including pesticides, dyes, detergents, and medicinal chemicals (Sax and Lewis, 1987). Benzene has been used as a solvent for waxes, resins, and oils and has been reported in gasoline at concentrations of less than 5 percent by volume (National Research Council, 1977). Benzene has been listed as a carcinogen by the U.S. Environmental Protection Agency (Budavari and others, 1989).

Bis-(2-ethylhexyl) phthalate was detected in the water sample from well MW-1 at $13 \mu \mathrm{g} / \mathrm{L}$. This concentration did not exceed Kansas drinking-water regulations (table 9). This compound is used as a plasticizer and is ubiquitous; its detection at small concentrations such as this could result from sample processing as well as from actual presence in the ground water.

Chloroethane (ethyl chloride) was detected in the water sample from well MW-6 at a concentration of $3.5 \mu \mathrm{g} / \mathrm{L}$. This concentration did not exceed the $\mathrm{KNL}$ of $3.7 \mu \mathrm{g} / \mathrm{L}$ (table 9). Chloroethane is used as a refrigerant and as a solvent for phosphorus, sulfur, fats, oils, resins, and waxes. It is also used in the manufacture of tetraethyl lead and as an insecticide (Sax and Lewis, 1987).

1,1-dichloroethane (ethylidene chloride) was detected in the water sample from well MW-6 at $1.0 \mu \mathrm{g} / \mathrm{L}$. The sample exceeded the KNL of $0.50 \mu \mathrm{g} / \mathrm{L}$ but not the KAL of $5.0 \mu \mathrm{g} / \mathrm{L}$. 1,1-dichloroethane is used as an extraction solvent and as a fumigant (Sax and Lewis, 1987).

Methylene chloride was detected in the water sample from well MW-6 at $0.2 \mu \mathrm{g} / \mathrm{L}$. KAL and KNL concentrations were not exceeded for this compound. Methylene chloride is used in paint removal, solvent degreasing, plastics processing, a blowing agent in foams, solvent extraction, and aerosol propellant (Sax and Lewis, 1987).

Toluene was detected in the water sample from well MW-10 at a concentration of $0.2 \mu \mathrm{g} / \mathrm{L}$. This concentration did not exceed any drinking-water regulations. Toluene has a variety of uses including as a compound in aviation gasoline, as a solvent for paints, as an adhesive solvent for toys and model airplanes, and in explosives (trinitrotoluene, TNT) (Sax and Lewis, 1987).

1,2-trans-dichloroethene (acetylene dichloride) was detected in the water sample from well MW-6 at a concentration of $0.3 \mu \mathrm{g} / \mathrm{L}$. The concentration in water from well MW-6 did not exceed the KNL of $7.0 \mu \mathrm{g} / \mathrm{L}$. 1,2-trans-dichloroethene is used as a solvent for organic materials, dye extraction, perfumes, lacquers, and thermoplastics (Sax and Lewis, 1987). 


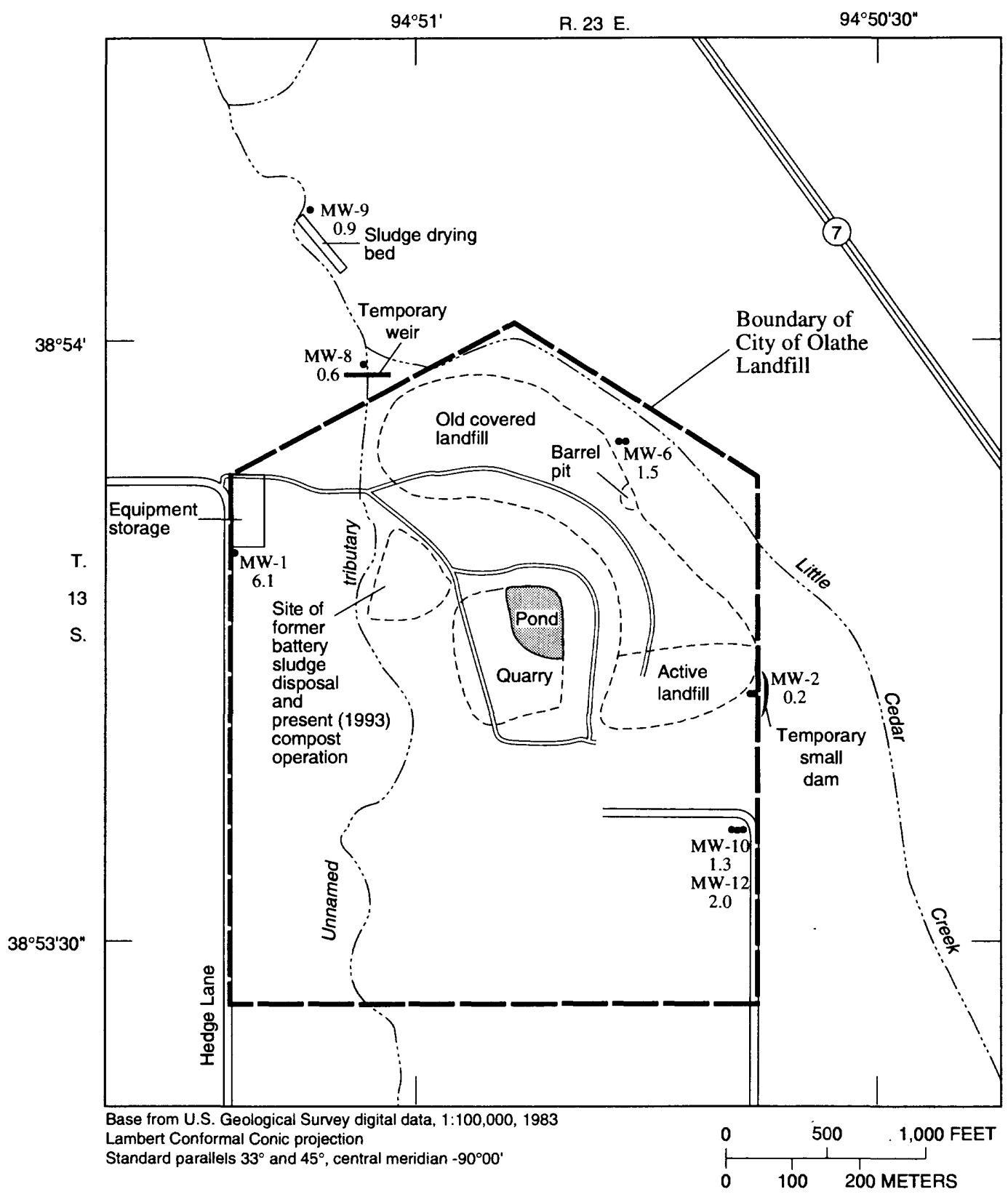

EXPLANATION

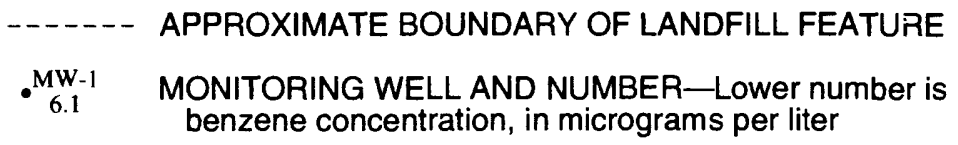

Figure 11. Distribution of benzene concentrations in water in vicinity of the City of Olathe Landfill, December 1990-February 1991. 
Xylene was detected in the water sample from well MW-6 at concentrations of $1.0 \mu \mathrm{g} / \mathrm{L}$. This concentration did not exceed any drinking-water regulations. Xylene is used in aviation gasoline, in protective coatings, as a solvent for alkyd resins, lacquers, enamels, and rubber cements, and in the synthesis of organic chemicals (Sax and Lewis, 1987).

\section{EFFECTS OF LANDFILL ON GROUND- WATER QUALITY}

Leachate from the City of Olathe Landfill has some effect on the physical properties of water and on concentrations of inorganic constituents at downgradient locations. In the Plattsburg Limestone, calcium, magnesium, sodium, bicarbonate, ammonia, barium, iron, and manganese concentrations downgradient of the landfill were larger than concentrations in upgradient ground water. Dissolved-solids concentrations, including calcium, sodium, bicarbonate, chloride, barium, iron, and manganese, in samples collected from monitoring well MW-6 and the nearby seep at sampling site CR-5 were substantially larger than concentrations found in water from well MW-2 and in ground water from the shallower Stanton Limestone at well MW-10. These larger concentrations may be due to the dissolution of minerals composing shale, used as a cover material, facilitated by reducing conditions under parts of the landfill.

Concentrations of calcium and sodium in the aquifer in the Wyandotte Limestone varied between upgradient and downgradient ground water. The concentration of sodium decreased and the concentration of calcium increased as water in the Wyandotte Limestone moved beneath the landfill. The concentrations of these constituents may be affected by landfill leachate (moving downward and mixing with the underlying ground water) and by an ion-exchange process within the aquifer. The water samples collected at nearby creek sites had chemical characteristics similar to the samples collected from wells downgradient of the landfill, indicating that the landfill also may be affecting water quality in the creeks.

Nearly all concentrations of inorganic constituents in downgradient surface-water samples were larger than the concentrations in surface-water samples collected upgradient of the landfill, indicating that the landfill is affecting water quality in the creeks. The concentrations of these constituents in Little Cedar Creek did not change upstream of the confluence with the unnamed tributary. The concentrations of these constituents in the unnamed tributary that drains the landfill were much larger than the concentrations in Little Cedar Creek. Concentrations of these constituents in the sample collected downstream of the confluence of these two creeks showed the effects of the mixing of the two sources of water.

The presence of organic compounds in the ground-water samples collected from wells screened in the Plattsburg Limestone (wells MW-2 and MW-6) indicates that the landfill leachate is affecting the water quality. The largest concentrations of several organic compounds occurred in water from well MW-6. The most likely explanation as to the largest concentrations of most volatile organic compounds (VOC's) in water from well MW-6 is that leachate from the old section of the landfill is contributing to the degradation of the quality of ground water.

Benzene was detected in every well sampled, with the largest concentrations detected in the water samples upgradient of the landfill, indicating a source other than the landfill. Because benzene concentrations were detected in samples from all of the monitoring wells, the most likely possibility could be a source upgradient of the landfill affecting all of the ground water in the area. The benzene concentration in the sample from well MW-1 could be explained by the proximity to the equipment storage building. The building is 100 feet north of well MW-1. Fuels and other solvents are stored in this building and could be the source of benzene concentrations in water from well MW-1. Another possible explanation could be that the direction of flow in the Wyandotte Limestone changes so that well MW-1 was not upgradient of the landfill for a period of time, and benzene from the landfill moved toward the well. It should be noted that this situation was not observed during the study period.

\section{SUMMARY AND CONCLUSIONS}

An investigation of the hydrogeology and water quality in the vicinity of the City of Olathe Landfill near Olathe, Kansas, was conducted from October 1990 through April 1993. The geology of Johnson County, Kansas, and in the vicinity of the landfill consists of alternating limestone and shale layers of Pennsylvanian age. The top of the bedrock at and near the City of Olathe Landfill generally is 0.5 to 15 feet below land surface. The Wyandotte Limestone is the 
shallowest bedrock formation that underlies the entire landfill and is exposed in both creeks. The thickness of the Wyandotte Limestone is not known because wells installed for this study penetrated only 10 to 30 feet of this formation. The thickness of the Bonner Springs Shale overlying the Wyandotte Limestone varies from about 10 to 40 feet. The next formation is the Plattsburg Limestone, generally 5 to 15 feet thick. The overlying Vilas Shale ranges from 10 to 15 feet thick. The Stanton Limestone is the uppermost formation and is present in the central and southeast corner of the landfill. The topsoil in the immediate area of the landfill consists of six soil types of silt loam and silty clay loam.

Little Cedar Creek is located east and north of the landfill. An unnamed tributary of the Little Cedar Creek flows through the west half of the landfill and discharges to Little Cedar Creek north of the landfill boundary. Ground-water flow in the Plattsburg Limestone is outward away from a quarry pond, beneath the landfill until it discharges at the outcrops where the two creeks have eroded part of the limestone. Groundwater flow in the Wyandotte Limestone was from south to north during the period of investigation.

Four water types were found in the study areacalcium magnesium bicarbonate, magnesium bicarbonate, sodium bicarbonate, and calcium bicarbonate. Chemical analysis of water from downgradient monitoring wells and downstream surface-water sampling sites indicates relatively large concentrations of several constituents. The inorganic constituents in the ground water that are most affected in the vicinity of the landfill are calcium, magnesium, sodium, bicarbonate, ammonia, barium, iron, and manganese. Large concentrations of these constituents occurred in ground water sampled from a well and a seep in the Plattsburg Limestone and probably were derived from the old covered section of the landfill. Water sampled from well MW-9 had similar chemical characteristics to the water sampled at surface-water sampling site $\mathrm{CR}-4$, indicating that fractures in the Wyandotte Limestone in this area are allowing the surface water to infiltrate to the ground water.

Analysis of water samples collected between December 1990 and February 1991 indicate that eight volatile organic compounds were present in water from monitoring wells. Of these eight, six were detected in water from monitoring well MW-6, screened in the Plattsburg Limestone immediately downgradient of the landfill. Benzene was the only volatile organic compound detected at a concentration larger than Kanșas and Federal drinking-water regulations. The concentration that exceeded these regulations was detected in water upgradient of the landfill in the Wyandotte Limestone (well MW-1). Benzene was detected in water from all of the monitoring wells, indicating a source upgradient of the landfill. There was no evidence of the landfill contributing to the concentration of benzene downgradient.

Further monitoring, consisting of quarterly sampling, would provide improved knowledge of seasonal variations of chemical constituents, water levels, and direction of ground-water movement. With additional drilling and sampling, an improved definition of the upgradient water quality could be determined. Yearly sampling would provide knowledge of the long-term effects of the landfill on the shallow aquifers.

\section{SELECTED REFERENCES}

American Public Health Association, 1976, Standard methods for the examination of water and wastewater (14th ed): Washington D.C., American Public Health Association, American Public Water Works Association, Water Pollution Control Federation, 1193 p.

Apgar, M.A., and Langmuir, Donald, 1971, Groundwater pollution potential of a landfill above the water table: Ground Water, v. 9, no. 6, p. 76-93.

Baedecker, M.J., and Back, William, 1979, Hydrogeological processes and chemical reactions at a landfill: Ground Water, v. 17, no. 5, p. 429-437.

Bouwer, Herman, and Rice, R.C., 1976, A slug test for determining hydraulic conductivity of unconfined aquifers with completely or partially penetrating wells: Water Resources Research, v. 12, no. 3, p. 423-428.

Budavari, Susan, O'Neil, M.J., Smith, Ann, and Heckelman, P.E., eds., 1989, The Merck index-An encyclopedia of chemicals, drugs, and biologicals (11th ed): Rahway, New Jersey, Merck and Co., Inc., $1606 \mathrm{p}$.

Christensen, T.H., Cossu, Raffaello, and Stegmann, Rainer, 1989, Sanitary landfilling-Process, technology and environmental impact: New York, Harcourt Brace Jovanovich Publ., p. 29-51.

Fetter, C.W., 1988, Applied hydrogeology (2d ed): Columbus, Ohio, Merrill Publishing Co., 592 p.

Fishman, M.J., and Friedman, L.C., eds., 1989, Methods for determination of inorganic substances in water and fluvial sediments: U.S. Geological Survey Techniques of Water-Resources Investigations, book 5, chap. A1, $545 \mathrm{p}$. 
Francis, C.W., and Auerbach, S.I., 1983, Environment and solid waste-Characterization, treatment, and disposal: Boston, Butterworth Publ., p. 315-521.

Freeze, R.A., and Cherry, J.A., 1979, Groundwater: Englewood Cliffs, New Jersey, Prentice-Hall, Inc., 604 p.

Heck, B.A., Myers, N.C., and Hargadine, D.A., 1992, Hydrogeology and ground-water-quality conditions at the Reno County Landfill, south-central Kansas, 1990-91: U.S. Geological Survey Water-Resources Investigation Report 92-4169, 56 p.

Hem, J.D., 1985, Study and interpretation of the chemical characteristics of natural water (3rd ed): U.S. Geological Survey Water-Supply Paper 2254, 263 p.

Kansas Department of Health and Environment, 1986, Explanation of your drinking vvater analysis: Topeka, Kansas, October 28, 1986, pamphlet.

Myers, N.C., and Bigsby, P.R., 1989, Hydrogeology and ground-water-quality conditions at the Geary County Landfill, northeast Kansas, 1988: U.S. Geological Survey Water-Resources Investigation Report 89-4114, 41 p.

1990 , Hydrogeology and ground-water-quality conditions at Emporia-Lyon County Landfill, eastern Kansas, 1988: U.S. Geological Survey Water-Resources Investigations Report 90-4043, 42 p.

National Oceanic and Atmospheric Administration, 1974-92, Climatological data, monthly summary, Kansas: Ashville, North Carolina (published monthly).

National Research Council, 1977, Drinking water and health: Washington, D.C., National Academy of Sciences, $939 \mathrm{p}$.

O'Connor, H.G., 1971, Geology and ground-water resources of Johnson County, northeastern Kansas: Kansas Geological Survey Bulletin 203, 68 p.

Sax, N.I., and Lewis, Richard, Sr., 1987, Hawley's condensed chemical dictionary (11th ed): New York, Van Nostrand Reinhold Co., 1288 p.

Steiner, R.C., Fungaroli, A.A., Schoenberger, R.J., and Purdom, P.W., 1971, Criteria for sanitary landfill development: Public Works, v. 102, no. 3, p. 77-79.

Stiff, H.A., Jr., 1951, The interpretation of chemical water analyses by means of patterns: Journal of Petroleum Technology, v. 3, no. 10, p. 15-17.

Tchobanoglous, George, Theisen, Hilary, and Eliassen, Rolf, 1977, Solid wastes- Engineering principles and management issues: New York, McGraw-Hill, 621 p.
Thurman, E.M., 1985, Organic geochemistry of natural water: Boston, Martinus Nijihoff/Dr. W. Junk Publ., $497 \mathrm{p}$.

Todd, D.K., 1980, Groundwater hydrology: New York, John Wiley and Sons, $535 \mathrm{p}$.

U.S. Department of Agriculture, 1979, Soil survey of Johnson County, Kansas: Washington D.C., 93 p.

U.S. Environmental Protection Agency, 1973, An environmental assessment of potential gas and leachate problems at land disposal sites: U.S. Environmental Protection Publication SW-100.of., 33 p.

1975, Gas and leachate from land disposal of municipal solid waste-Summary report: Cincinnati, Ohio, U.S. Environmental Protection Agency, Municipal Research Laboratory, 1975.

1987, National primary drinking-water regulations-Synthetic organic chemicals (40 CFR Parts 141 and 142): Federal Register, v. 52, no. 130, July 8, 1987 , p. 25690-25702.

1990a, Maximum contaminant level goals (subpart $F$ of part 141, National primary drinking-water regulations): U.S. Code of Federal Regulations, Title 40, Parts 100 to 149, revised as of July 1, 1990, p. 620.

$1990 \mathrm{~b}$, Maximum contaminant levels (subpart B of part 141, National primary drinking-water regulations): U.S. Code of Federal Regulations, Title 40, Parts 100 to 149, revised as of July 1, 1990, p. 559. 1990c, National revised primary drinking-water regulations-Maximum contaminant levels (subpart $\mathrm{G}$ of part 141, National primary drinking-water regulations): U.S. Code of Federal Regulations, Title 40, Parts 100 to 149, revised as of July 1, 1990, p. 621. 1990d, National secondary drinking-water regulations (part 143, National secondary drinking-water regulations): U.S. Code of Federal Regulations, Title 40, Parts 100 to 149, revised as of July 1, 1990, p. 674.

1990e, Maximum contaminant levels (subpart D of part 141, National primary drinking-water regulations): U.S. Code of Federal Regulations, Title 40, Parts 100 to 149, revised as of July 1, 1990, p. 559.

Wershaw, R.L., Fishman, M.J., Grabbe, R.R., and Lowe, L.E., eds., 1987, Methods for the determination of organic substances in water and fluvial sediments: U.S. Geological Survey Techniques of Water-Resources Investigations, book 5, chap. A3, $80 \mathrm{p}$. 